\title{
Accommodation of transpressional strain in the Arabia-Eurasia collision zone: new constraints from (U-Th)/He thermochronology in the Alborz mountains, north Iran
}

\author{
Paolo Ballato, ${ }^{1}$ Daniel F. Stockli, ${ }^{2,3}$ Mohammad R. Ghassemi, ${ }^{4}$ Angela Landgraf, ${ }^{1}$ \\ Manfred R. Strecker, ${ }^{1}$ Jamshid Hassanzadeh, ${ }^{5}$ Anke Friedrich, ${ }^{6}$ and Saeid H. Tabatabaei ${ }^{7}$ \\ Received 18 May 2012; accepted 20 November 2012; published 28 January 2013.
}

[1] The Alborz range of N Iran provides key information on the spatiotemporal evolution and characteristics of the Arabia-Eurasia continental collision zone. The southwestern Alborz range constitutes a transpressional duplex, which accommodates oblique shortening between Central Iran and the South Caspian Basin. The duplex comprises NW-striking frontal ramps that are kinematically linked to inherited E-W-striking, right-stepping lateral to obliquely oriented ramps. New zircon and apatite (U-Th)/He data provide a high-resolution framework to unravel the evolution of collisional tectonics in this region. Our data record two pulses of fast cooling associated with SW-directed thrusting across the frontal ramps at $~ 18-14$ and 9.5-7.5 Ma, resulting in the tectonic repetition of a fossil zircon partial retention zone and a cooling pattern with a half U-shaped geometry. Uniform cooling ages of $\sim 7-6 \mathrm{Ma}$ along the southernmost $\mathrm{E}-\mathrm{W}$ striking oblique ramp and across its associated NW-striking frontal ramps suggests that the ramp was reactivated as a master throughgoing, N-dipping thrust. We interpret this major change in fault kinematics and deformation style to be related to a change in the shortening direction from NE to N/NNE. The reduction in the obliquity of thrusting may indicate the termination of strike-slip faulting (and possibly thrusting) across the Iranian Plateau, which could have been triggered by an increase in elevation. Furthermore, we suggest that $\sim 7-6-\mathrm{m}$.y.-old S-directed thrusting predated inception of the westward motion of the South Caspian Basin.

Citation: Ballato, P., D. F. Stockli, M. R. Ghassemi, A. Landgraf, M. R. Strecker, J. Hassanzadeh, A. Friedrich, and S. H. Tabatabaei (2012), Accommodation of transpressional strain in the Arabia-Eurasia collision zone: new constraints from (U-Th)/He thermochronology in the Alborz mountains, N Iran, Tectonics, 32, 1-18, doi:10.1029/2012TC003159.

\section{Introduction}

[2] Oblique convergence of lithospheric plates and their ultimate collision generates transpressional deformation on a variety of spatial scales [e.g. Jones and Tanner, 1995; Oldow et al., 1990; Tikoff and Teyssier, 1994; Teyssier et al., 1995; Dewey et al., 1998; Miller, 1998; Jiang et al., 2001].

\footnotetext{
${ }^{1}$ Institut für Erd- und Umweltwissenschaften, Universität Potsdam, Potsdam, Germany.

${ }^{2}$ Department of Geology, University of Kansas, Lawrence, Kansas, USA.

${ }^{3}$ Now at Department of Geological Sciences, Jackson School of Geosciences, Austin, Texas, USA.

${ }^{4}$ Research Institute for Earth Sciences, Geological Survey of Iran, Tehran, Iran.

${ }^{5}$ Division of Geological and Planetary Sciences, California Institute of Technology, Pasadena, California, USA.

${ }^{6}$ Institut für Geo- und Umweltwissenschaften, Ludwig-Maximilians Universität München, Munich, Germany.

${ }^{7}$ Building and Housing Research Center, Tehran, Iran.

Corresponding author: P. Ballato, Institut für Erd-und Umweltwissenschaften, Universität Potsdam, D-14476 Potsdam, Germany. (ballato@geo.uni-potsdam.de)

(C)2012. American Geophysical Union. All Rights Reserved. 0278-7407/12/2012TC003159
}

Transpressional deformation may be accommodated along relatively narrow zones, sometimes coinciding with plate boundaries (e.g., the San Andreas Fault in California, [Spotila et al., 2007]), along major strike-slip faults in orogenic systems (e.g., the Denali Fault in Alaska, [Fitzgerald et al., 1995), or across extensive areas of deformation, far away from plate boundaries in continental interiors [e.g., Mongolian Altai, Cunningham, 2005]. Transpressional strain may be accommodated either through oblique slip [e.g., Wilcox and Harding, 1973] or through strain partitioning into discrete deformation domains of kinematically linked dip-slip and strike-slip faults [e.g., Jones and Tanner, 1995]. Such faults may be sub-parallel to a master strike-slip fault or they may comprise complex anastomosing fault arrays in transpressional duplexes [Sanderson and Marchini, 1984; Woodcock and Fischer, 1986]. The variability and complexity of fault geometry and associated kinematics can result from a long-term history of deformation, and may include a change in shortening direction or the reactivation of inherited structures, which ultimately produces highly disparate patterns of faulting and exhumation in space and time [e.g., Holdsworth et al., 1997; Miller, 1998; Cunningham, 2005; Dewey et al., 1998; Landgraf et al., 2009]. Documenting and assessing such variability is a first-order goal 
for unraveling long-term tectonic processes in orogens and for understanding the present-day seismotectonic characteristics and associated hazards.

[3] The Arabia-Eurasia collision zone is an extensive, actively deforming region [e.g., Vernant et al., 2004] with a complex and protracted deformational history [e.g., Berberian and King, 1981] (Figure 1). According to plate-tectonic reconstructions, the motion of Arabia with respect to Eurasia changed from about NE to $\mathrm{N}$ at $\sim 20 \mathrm{Ma}$, coupled with a decrease in plate convergence rates [McQuarrie et al.,
2003]. This resulted in a pronounced obliquity between the convergence vectors and the pre-strained crustal fabric of the lower and upper plates (Figure 1). This obliquity has strongly dictated the deformation style of collision and linked exhumation patterns. For example, in the Alborz [Jackson et al., 2002] and Zagros [Talebian and Jackson, 2004; Alipoor et al., 2012] mountains, oblique strain is partitioned into thrust and strike-slip motion on separate parallel fault systems. Conversely, in the Urumieh-Dokhtar Volcanic Zone [Morley et al., 2009] and the Sanandaj-Sirjan Zone [Mohajjel
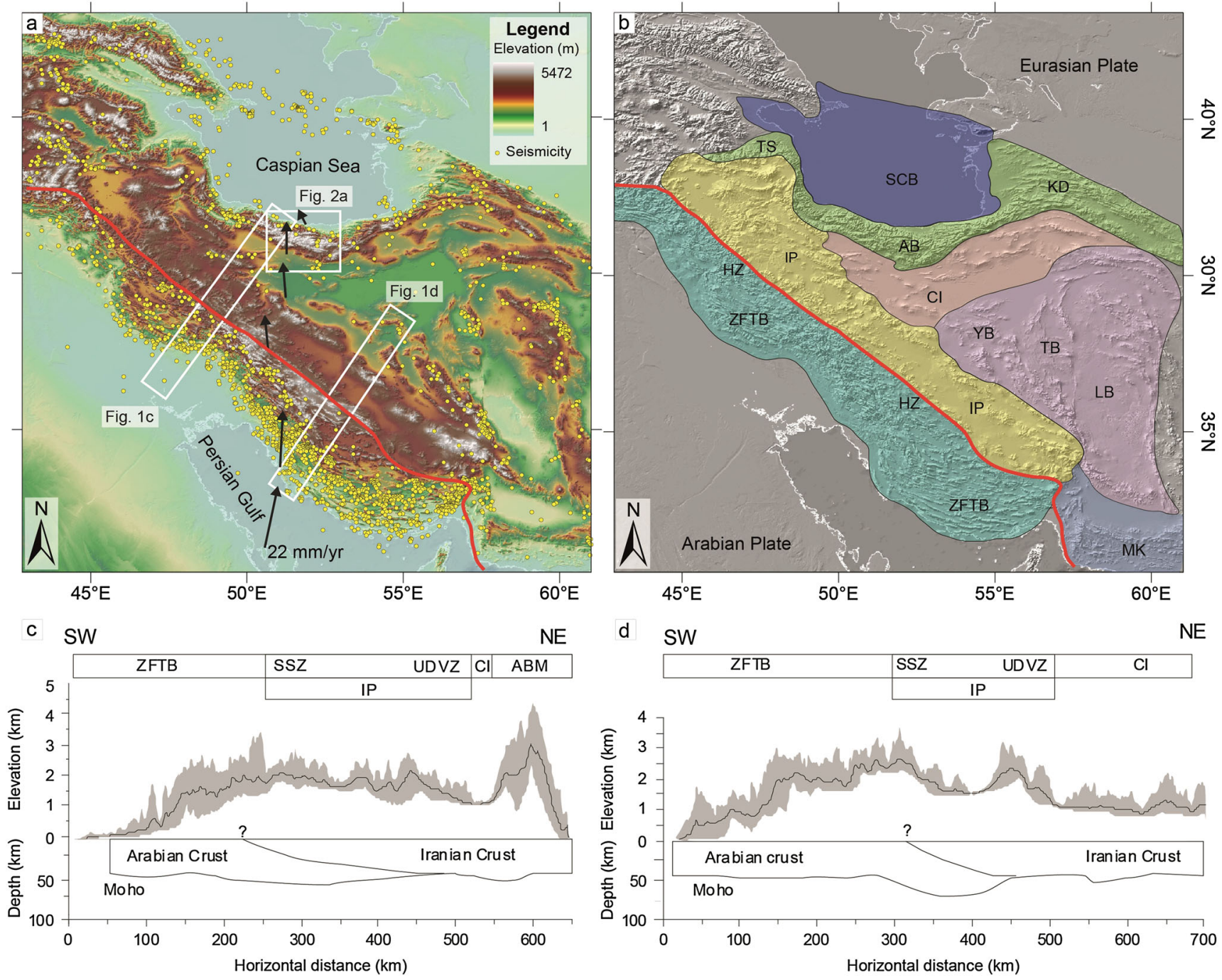

Figure 1. (a) DEM showing seismicity (data from Engdahl et al. [2006]) across the Arabia-Eurasia collision zone and GPS data (black vectors) at the longitude of Tehran [Vernant et al., 2004]. The red line represents the Arabian-Iranian suture zone, which is interpreted to coincide with the fault trace of the Main Zagros Reverse Fault. (b) Hillshade model with the major tectonic zones of Iran, showing the location of South Caspian Basin (SCB), Alborz mountains (AB), Talesh mountains (TS), Kopeh-Dagh (KD), Central Iran (CI), Urumieh-Dokhtar Volcanic Zone (UDVZ), Sanandaj-Sirjan Zone (SSZ), Iranian Plateau (IP), Zagros Simply Folded Belt (ZSFB), Lut Block (LB), Yazd Block (YB), Tabas Block (TB) and Makran (MK). The Iranian Plateau is the extensive, NW-trending high-elevation area on the Eurasian plate, which includes the SSZ and the UDVZ (see section 6.5 for our definition of Iranian Plateau). (c) and (d) are topographic swath profiles across the collision zone showing crustal thicknesses [Paul et al., 2010] and inferred underthrusting of the Arabian Plate. Note the pronounced obliquity (up to $45^{\circ}$ ) between GPS vectors and the major NW-striking structures bounding mountain ranges (ZFSB, SSZ and UDVZ). Obliquity in the Alborz mountains changes along strike from a few degrees to $\sim 60^{\circ}$ along its western and eastern side, respectively. 
et al., 2003], oblique slip is accommodated by a complex array of anastomosing faults (Figure 1). Additional complexity in the deformation arises from rigid blocks within the collision zone, which may have experienced variations in the relative motion, as documented for the Caspian Sea [Jackson et al., 2002; Djamour et al., 2010] and as suggested for Central Iran [Ballato et al., 2011].

[4] The Alborz mountains of N Iran form an intracontinental orocline in the northern sector of the Arabia-Eurasia collision zone (Figure 1). With a length of $700-800 \mathrm{~km}$, a width of $60-130 \mathrm{~km}$, and peak elevations up to $\sim 5.6 \mathrm{~km}$, this collisional mountain range forms an efficient orographic barrier that impacts erosion and sedimentation patterns. In light of these characteristics, the Alborz mountains record a complex tectono-sedimentary evolution, involving major changes in the kinematic regime [Axen et al., 2001; Allen et al., 2003; Guest et al., 2006a; Zanchi et al., 2006; Landgraf et al., 2009; Ballato et al., 2011]. Overall, the spatiotemporal evolution of deformation appears to result from the interaction between the relatively rigid South Caspian Basin in the north and the Central Iranian Block to the south [e.g., Allen et al., 2003]. At their location between these major morphotectonic provinces, the Alborz mountains provide a well suited environment to investigate how changes in the kinematic regime affect an orogen and to improve our general knowledge about accommodation of transpressional strain in a collisional setting.

[5] The southwest mountain front of the Alborz mountains constitutes a complex thin-skinned transpressional duplex (here defined as the North Tehran Transpressional Duplex, Figure 2 [Guest et al., 2006a; Landgraf et al., 2009]) composed of thick volcaniclastic sediments (locally up to $8 \mathrm{~km}$ ) deposited between 55-50 and $\sim 36 \mathrm{Ma}$ (Karaj Formation [Berberian and King, 1981; Ballato et al., 2011; Verdel et al., 2011]). These units have apatite- and zircon-bearing lithologies that provide a means to determine sediment depositional ages and the thermal histories of the rock units of the duplex. Here, we present new zircon and apatite (U-Th)/He cooling ages ( $\mathrm{ZHe}$ and AHe, respectively) across the transpressional duplex that reveal the timing and magnitude of rock uplift, the patterns of exhumation, and the kinematic evolution of the duplex within the regional context of transpressional and collisional processes. In particular, we first document two pulses of fast cooling in the SW Alborz mountains and exhumation-related deformation at $\sim 18$ to $14 \mathrm{Ma}$ and at $\sim 9.5$ to $7.5 \mathrm{Ma}$, associated with the development of the transpressional duplex during NE-oriented shortening. Second, we discuss a third tectonic pulse at 7-6 Ma, which was coupled with the reactivation of the southernmost E-W-striking lateral/oblique ramp as a major frontal thrust. Most likely, this latter tectonic phase occurred in response to a change in the shortening direction to a more orogen-perpendicular orientation with respect to the pre-existing faults. Our findings are compatible with the acceleration of tectonic processes (i.e., faulting, folding, exhumation, subsidence, etc.) observed across the entire ArabiaEurasia collision zone starting from $\sim 20 \mathrm{Ma}$ [Ballato et al., 2011; Van Hunan and Allen, 2011; Mouthereau et al., 2012], a kinematic changeover possibly associated with the topographic evolution of the Iranian Plateau by $\sim 7-6 \mathrm{Ma}$, and the onset of westward motion the South Caspian Basin induced by subduction processes underneath the northern Caspian Sea after approximately $6 \mathrm{Ma}$.

\section{Geologic Setting}

[6] The Alborz mountains are a sinuous, double-verging orogen, which presently accommodates about one third of the Arabia-Eurasia plate convergence [Vernant et al., 2004]. Oblique convergence is accommodated through a combination of left-lateral strike-slip $(\sim 7$ and $\sim 3 \mathrm{~mm} / \mathrm{yr}$ in the eastern and central western part of the orogen, respectively) and thrust faulting $(\sim 2$ and $\sim 6 \mathrm{~mm} / \mathrm{yr}$ in the eastern and central western sectors, respectively [Djamour et al., 2010]). The pronounced difference in along-strike deformation rates is due to the variation in obliquity between the major orogenic structural trends and the $\sim \mathrm{N} 20^{\circ}$ E [Masson et al., 2007] shortening direction (Figures 1 and 2). Seismicity patterns indicate a partitioning of oblique strain into strike-slip and dip-slip faulting [Jackson et al., 2002; Tatar et al., 2007].

[7] The Alborz mountains are characterized by a strongly pre-strained crust with inherited anisotropies resulting from the Devonian opening [e.g., Horton et al., 2008] and Late Triassic closure of the Paleo-Tethys ocean [e.g., Horton et al., 2008; Zanchi et al., 2009; Wilmsen et al., 2009], the Middle-Late Jurassic opening of the South Caspian Basin [e.g., Brunet et al., 2003; Wilmsen et al., 2009], a Late Cretaceous to Early Paleocene phase of contractional deformation [e.g., Guest et al., 2006b; Yassaghi and Madanipour, 2008; Yassaghi and Naeimi, 2011], and a Late Paleocene to Late Eocene magmatic flare-up associated with extensional/ transtensional tectonism [e.g., Berberian and King, 1981; Ballato et al., 2011; Verdel et al., 2011]. Contractional deformation in response to an early stage of the Arabia-Eurasia continental collision ("soft collision" at $\sim 36 \mathrm{Ma}$, sensu Ballato et al. [2011]) started at low rates during the Late Eocene-Early Oligocene as revealed by the history of foreland-basin sedimentation [Ballato et al., 2011] and apatite fission-track cooling ages [Rezaeian et al., 2012]. An acceleration of shortening rates coupled with the development of higher topography and exhumation of deeper rock units, however, must have occurred starting from $\sim 20 \mathrm{Ma}$ [Allen et al., 2003; Ballato et al., 2008, 2010, 2011; Rezaeian et al., 2012]. The Early Miocene acceleration of deformation and exhumation rates has been described in different sectors of the collision zone [e.g., Agard et al., 2011; Ballato et al., 2011; Mouthereau, 2011; Mouthereau et al., 2012; Khadivi et al., 2012]. This has been interpreted to reflect an increase in plate coupling due to the subduction of a progressively thicker and less dense Arabian lithosphere ("hard collision" sensu Ballato et al. [2011]). Subsequently, contractional deformation in the Alborz mountains seems to have occurred in episodic pulses as suggested by syn-orogenic deposits [Guest et al., 2007; Ballato et al., 2008] and thermochronologic data [Axen et al., 2001; Guest et al., 2006b; Rezaeian et al., 2012]. The last pulse at $5 \pm 2 \mathrm{Ma}$ is thought to reflect a tectonic reorganization of the collision zone [Westaway, 1994; Allen et al., 2004].

[8] Along the southwest flank of the Alborz, where the orogen changes from an approximately E-W- to a NW-SE orientation, is the North Tehran Transpressional Duplex [Guest et al., 2006a; Landgraf et al., 2009] (Figures 2 and 3). This transpressional duplex has accommodated oblique shortening along several NW-striking thrust faults (frontal ramps). From NE to SW, these comprise the central segments of the Mosha Fault (MFc), the Emamzadeh-Davoud Thrust (EDT), the Purkan-Vardij Thrust (PVT), and the northwest 

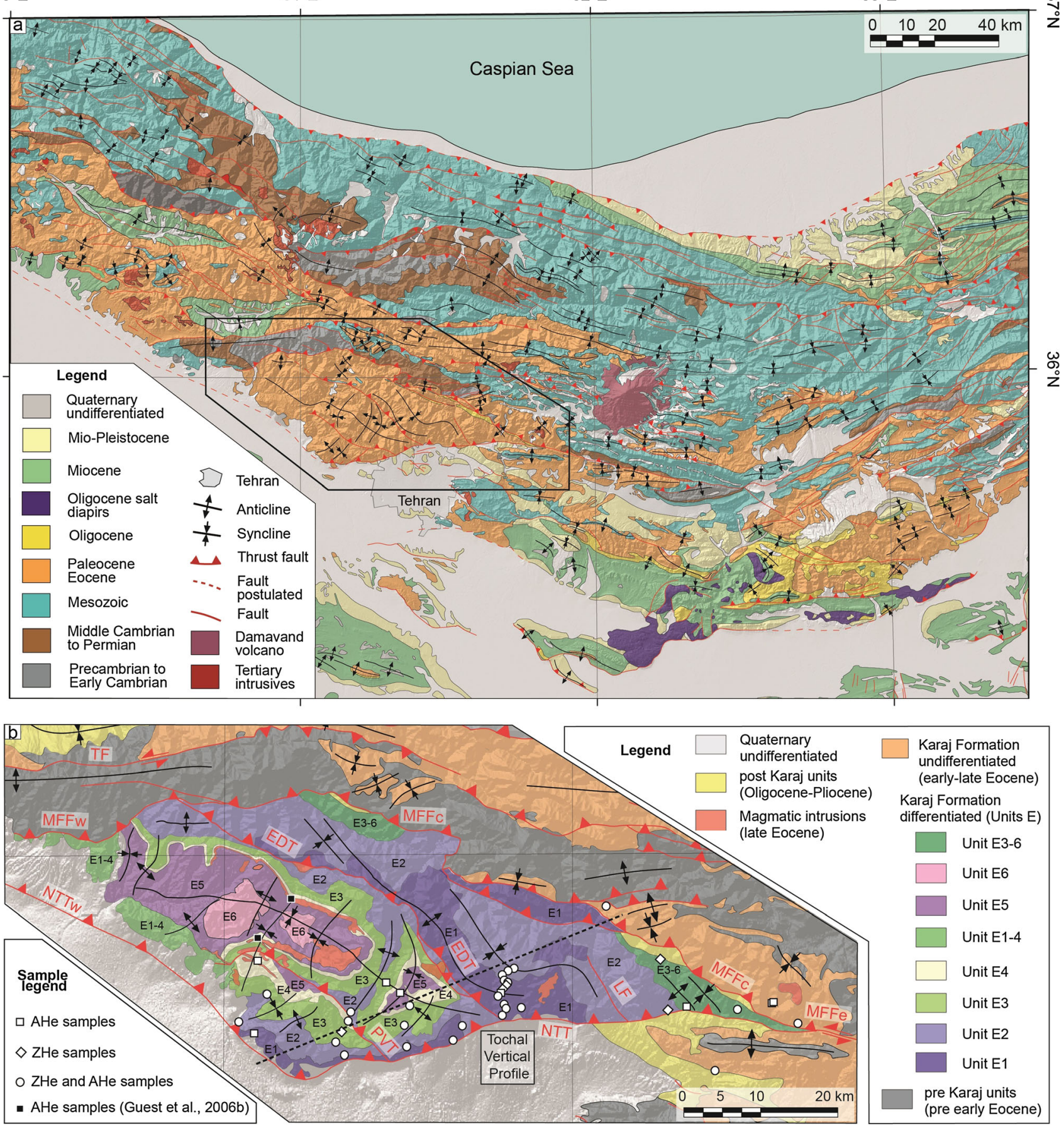

Figure 2. (a) Geologic map of the central Alborz mountains superimposed on a SRTM-based DEM. The black frame shows the location of figure 1b. The geology is modified and compiled after Amidi [1984], Amini et al. [1993, 2004], Haghipour et al. [1987], Vahdati Daneshmand et al. [1991], Vahdati Daneshmand and Saidi [1991], Aghanabati and Hamedi [1994], and Guest et al. [2006a]. (b) Geologic map of the North Tehran Thrust Transpressional Duplex superimposed on a SRTM-based DEM. The dashed bold black line shows the location of the geologic cross section of Figure 7. Abbreviations: MF Mosha Fault (w western, c central, e eastern segments), TF Taleghan Fault, NTT North Tehran Thrust (w western segment), EDT EmamzadehDavoud Thrust, PVT Purkan-Vardij Thrust, LF Lashgarak Fault. The Tochal vertical profile is located in the hanging wall of the EDT.

prolongation of the North Tehran Thrust (NTTw; Figures 2 and 3). Deformation also involved E-W striking, left-lateral strike-slip faults (lateral and oblique ramps), including the
Taleghan Fault (TF), and possibly the western segments of the Mosha Fault (MFw) along the northern margin of the duplex. The North Tehran Thrust (NTT) and the eastern 

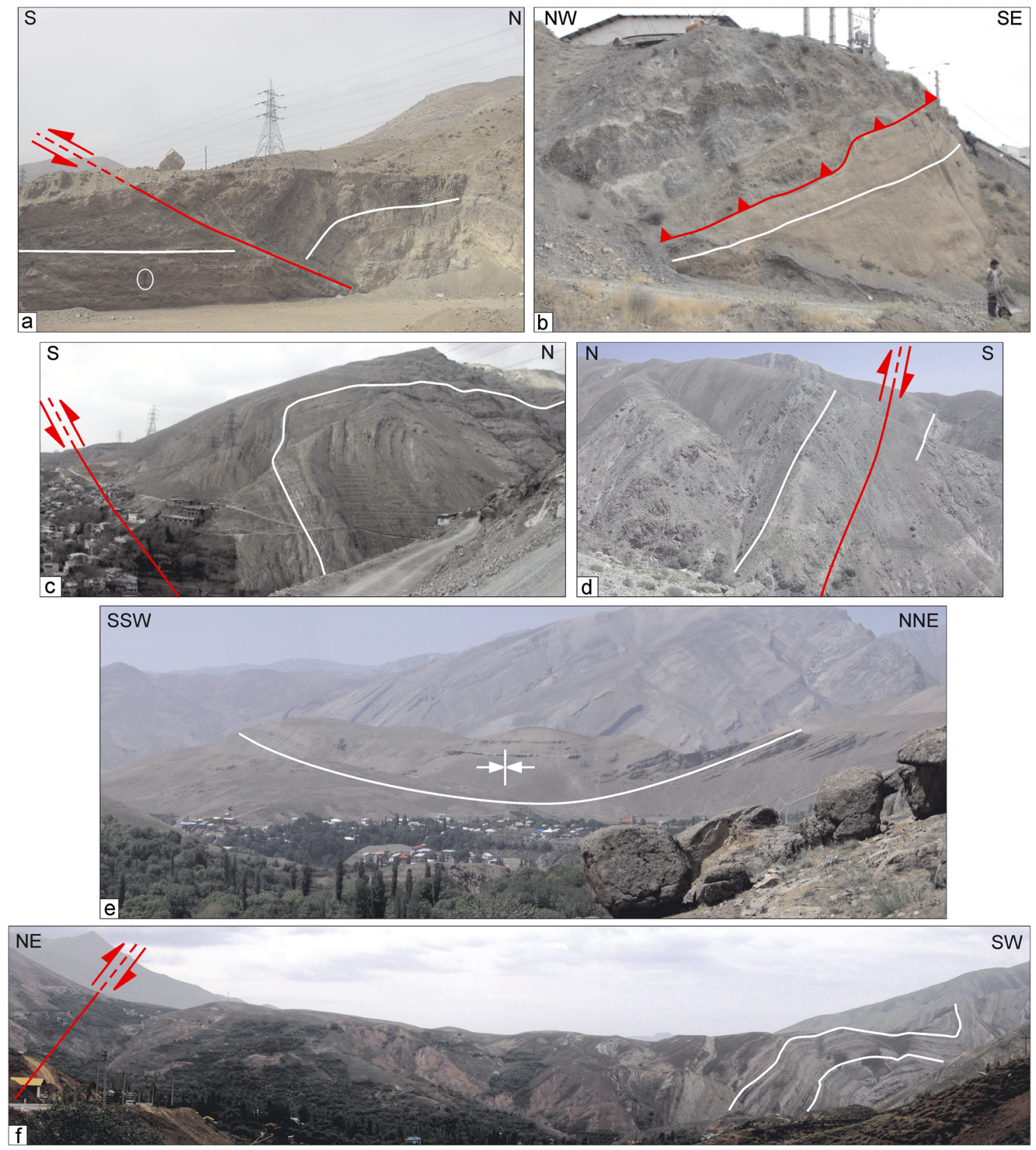

Figure 3. Some of the major structures within the North Tehran Transpressional Duplex. Red and white lines represent fault zone and bedding, respectively. The approximate coordinates of the outcrops are given in parenthesis. (a) Splay fault of the NTT causing the propagation of the deformation front into the Tehran plain $\left(35^{\circ} 45.758^{\prime} \mathrm{N}, 51^{\circ} 11.821^{\prime} \mathrm{E}\right)$; note the hammer in the circle for scale. (b) NTT fault zone with pervasively cataclasized volcanic rocks of the Karaj Formation thrusted onto fluvial and alluvial deposits of the foreland basin $\left(35^{\circ} 47.000^{\prime} \mathrm{N}, 51^{\circ} 18.860^{\prime} \mathrm{E}\right)$. (c) Overturned fold within the Karaj Formation in hanging wall of the PVT, in proximity to the NTT $\left(35^{\circ} 48.778^{\prime} \mathrm{N}, 51^{\circ} 22.779^{\prime} \mathrm{E}\right.$. (d) PVT fault zone juxtaposing tuffaceous rocks of unit E2 onto volcaniclastic conglomerates of unit E4 along a gently dipping contact (village location $35^{\circ} 48.730^{\prime} \mathrm{N}, 51^{\circ} 10.520^{\prime} \mathrm{E}$ ). (e) Core of the syncline located in hanging wall of the PVT. Strata constituting the northern limb of syncline are visible in background. Units in the foreground are part of the late Eocene magmatic intrusion mapped on Figure 2 (picture taken at $35^{\circ} 90.664^{\prime} \mathrm{N}, 51^{\circ} 12.629^{\prime} \mathrm{E}$ ). (f) Stratigraphic contact between folded tuffs of unit E6 and the red beds of the Lower Red Formation. The break in slope to the north is close to the MFc fault zone where undifferentiated volcanic rocks of the Karaj Formation are thrusted onto red beds (picture taken at $35^{\circ} 54.077^{\top} \mathrm{N}, 51^{\circ} 34.543^{`} \mathrm{E}$ ).

Mosha Fault segments (MFe) along the southern margin of the duplex (Figure 2) belong to this group of E-W-striking faults. NW-oriented axes of meso- and macroscale folds are associated with the major frontal ramps and are thus compatible with the present-day NNE shortening direction [Allen et al., 2003; Landgraf et al., 2009] (Figures 2 and 3). 
Locally, these NW-oriented folds refold older, NE-trending folds, which were probably generated during preceding NW-SE shortening. This interpretation is in agreement with fault-kinematic analysis and lateral offsets of geologic markers [Allen et al., 2003; Guest et al., 2006a; Zanchi et al., 2006; Landgraf et al., 2009; Ballato et al., 2011] (Figure 2). The NW-striking frontal ramps merge into the NTT along the southern margin of the duplex, while along the northern margin, fault linkage is incomplete. Oligocene to Early Miocene foreland-basin deposits are locally preserved in the hanging wall of the EDT, suggesting that uplift and erosion of the thrust sheet forming the duplex post-dates the Early Miocene [Ballato et al., 2011] (Figures 2 and 3).

\section{Materials and Methods}

[9] Low-temperature thermochronology offers the possibility to investigate the timing, magnitude, and rates of cooling in rocks within the upper few kilometers of the Earth's crust [e.g., Reiners and Brandon, 2006]. The application of zircon and apatite (U-Th)/He (ZHe and $\mathrm{AHe}$, respectively) thermochronology in contractional settings has significantly expanded our means to derive faulting chronologies and long-term rates of deformation and exhumation [e.g., Zeitler et al., 1987; Farley et al., 1996; Wolf et al., 1996; Farley, 2000; Reiners and Farley, 2001; Reiners et al., 2002; Wolfe and Stockli, 2010], as well as providing important clues about landscape evolution and regional tectonic processes [e.g. Spotila et al., 1998, 2001; Kirby et al., 2002]. Particularly the combination of multiple thermochronometers with different closure temperatures, such as the $\mathrm{AHe}\left(\sim 60^{\circ} \mathrm{C}\right.$ [e.g. Farley, 2000; Wolf et al., 1996]) and ZHe $\left(\sim 180^{\circ} \mathrm{C}\right.$ [e.g., Reiners et al., 2002; Wolfe and Stockli, 2010]) systems, reveals details of the cooling history of rocks that have resided within the upper $8-10 \mathrm{~km}$ of the Earth's crust.

[10] In order to constrain the timing of deformation and the spatiotemporal distribution of exhumation across the North Tehran Transpressional Duplex, we collected $30 \mathrm{ZHe}$ and 33 AHe samples from a 2-km-relief vertical transect across Tochal peak and from additional locations across the major thrust sheet within the duplex structure (Figure 2). Our samples included volcaniclastic sandstones, andesites, tuffs, and dikes of basic to intermediate composition belonging to the Eocene Karaj Formation. Most of the additional samples were collected on NNE-oriented transects along the major valleys draining the duplex, while the remainder was collected in the hanging walls of the NTT and of the MFc; finally, one sample was collected in the footwall of the duplex system east of Tehran along the southern limb of the Latyan anticline (Figure 2). To avoid ${ }^{4} \mathrm{He}$ loss due to reheating events associated with igneous intrusions emplaced during the final stage of Eocene magmatism, we did not collect any samples close to these intrusions [e.g., Ehlers, 2005]. This sampling strategy implies that our dated crystals should record only tectonic cooling.

[11] Mineral separations were performed using standard crushing, sieving, magnetic, and heavy liquid techniques at the University of Potsdam and the University of Kansas. For ZHe thermochronology, we analyzed three single-grain aliquots per sample following the protocol described in Wolfe and Stockli [2010], while for AHe thermochronology, we analyzed at least three single- to double-grain aliquots per sample following the protocol described in Stockli et al.
[2000]. Laboratory measurements were performed at the Isotope Geochemistry Laboratory of the University of Kansas. (U-Th)/He ages were calculated using the standard age equation [e.g., Farley and Stockli, 2002] and with FT corrections that assume a homogeneous $\mathrm{U}$ and $\mathrm{Th}$ distribution [Farley et al., 1996]. Reported age uncertainties $(2 \sigma)$ reflect the reproducibility of replicate analyses of laboratory-standard samples. Estimated analytical uncertainties are $\sim 6 \%(2 \sigma)$ for apatite and $\sim 8 \%(2 \sigma)$ for zircon He ages, respectively. Our (U-Th)/He cooling ages are summarized in Tables 1 and 2. Additional tables, including the results for all analyzed aliquots, are provided in the auxiliary material.

\section{Results}

[12] Our data reproduce well, and the cooling ages for most of the samples reported in Tables 1 and 2 represent the average over three aliquots. Apatite aliquots with mineral inclusions (most likely zircon or monazite microcrystals whose sizes were below microscope resolution) were discarded in the mean age calculation. Overall, our AHe ages reproduce better than $\mathrm{ZHe}$ ages, even if in a few cases we did not obtain enough high-quality apatite grains to obtain at least three inclusionfree aliquots.

\subsection{Zircon (U-Th)/He Data}

[13] The Tochal vertical transect exhibits an age-elevation relationship with an overall decrease in cooling ages with increasing paleo-depth/decreasing elevation from $25.7 \pm 2.1$ to $13.7 \pm 1.1 \mathrm{Ma}$ (Figures 4 and 5a; Table 1) The zircon-age profile is marked by a break in slope at about $18-14 \mathrm{Ma}$, corresponding to an elevation of $\sim 3-3.5 \mathrm{~km}$. Cooling ages above the break in slope vary between $25.7 \pm 2.1$ and $17.9 \pm 1.4 \mathrm{Ma}$ (except for one sample that yields a cooling age of $14.5 \pm 1.2 \mathrm{Ma}$, which is younger than the AHe age from the sample), while cooling ages below the break range from $16.3 \pm 1.3$ to $13.7 \pm 1.1 \mathrm{Ma}$ (Figure 4 ). The ZHe cooling ages of the additional samples beyond the vertical transect vary between $15.9 \pm 1.3$ and $47.3 \pm 3.8 \mathrm{Ma}$, except for one sample that yields two aliquots with ages of $70.4 \pm 5.6$ and $84.9 \pm 6.8 \mathrm{Ma}$. These ages are older than the rock depositional age (Figure 5a; Table 1). Within the individual thrust sheets of the duplex system, the youngest ages are systematically located proximal to the major frontal ramps (NTTw, PVT and EDT) and in the vicinity of the intersection of these faults with the NTT oblique ramp (Figure 5a). This pattern results in pronounced age contrasts across the principal frontal ramps, with younger cooling ages clustering in the hanging walls, except for the MFc, where hanging-wall ages are older than footwall ages (Figure 5a). Samples yielding cooling ages younger than $20 \mathrm{Ma}$ are located only in the hanging wall of the EDT (Figure 5a). Overall, the youngest cooling ages are associated with samples from the base of the Karaj Formation, while older ages were obtained from intermediate and upper parts of this unit (Figure 6; Table 1). Finally, the samples from outside the vertical profile exhibit a correlation between age and elevation, with older ages systematically located at higher elevations (Figure 7a).

\subsection{Apatite (U-Th)/He Data}

[14] The Tochal vertical transect shows a decrease in cooling ages with increasing paleo-depth/decreasing 


\section{BALLATO ET AL.: COLLISIONAL OBLIQUE STRAIN}

Table 1. Summary of Zircon (U-Th)/He Cooling Ages

\begin{tabular}{|c|c|c|c|c|c|c|c|c|c|c|}
\hline Sample & Age $[\mathrm{Ma}]$ & $\pm[\mathrm{Ma}]$ & Aliquotes & SD & Age group $^{a}$ & Latitude $\left(^{\circ}\right)$ & Longitude $\left(^{\circ}\right)$ & Elevation (m) & Unit & Structural location \\
\hline TH08-05 & 47,3 & 3,8 & 2 & 1,0 & 1 & 35,94312 & 51,53752 & 2002 & E undiff. & MF hw \\
\hline ТH08-07 & 24,9 & 2,0 & 3 & 7,6 & 2 & 35,82664 & 51,17648 & 2184 & E2 & PVT hw \\
\hline TH08-08 & 43,2 & 3,5 & 2 & 4,8 & 1 & 35,81436 & 51,17620 & 1969 & $\mathrm{E} 4$ & NTTw hw \\
\hline TH08-09-1 ${ }^{\mathrm{c}}$ & 70,4 & 5,6 & - & - & 1 & 35,80691 & 51,16795 & 1790 & E3 & NTTw hw \\
\hline TH08-09-2 & 84,9 & 6,8 & - & - & 1 & 35,80691 & 51,16795 & 1790 & E3 & NTTw hw \\
\hline TH08-10 & 39,4 & 3,1 & 3 & 4,5 & 1 & 35,78784 & 51,15915 & 1636 & E2 & NTTw hw \\
\hline TH08-13 & 21,7 & 1,7 & 3 & 2,1 & 2 & 35,84421 & 51,05709 & 1425 & $\mathrm{E} 2 / \mathrm{E} 3$ & NTTw hw \\
\hline ТH08-22 & 34,3 & 2,7 & 2 & 1,9 & 2 & 35,81032 & 51,82980 & 2310 & Intrusive & MF hw \\
\hline ТH08-24 & 38,3 & 3,1 & 3 & 6,3 & 1 & 35,75801 & 51,69988 & 1510 & E undiff. ${ }^{\mathrm{d}}$ & MF-NTT fw \\
\hline ТH08-27 & 39,3 & 3,1 & 3 & 2,4 & 1 & 35,87887 & 51,65311 & 2141 & E3-6 ${ }^{\mathrm{d}}$ & EDT hw \\
\hline SA-05 & 24,1 & 1,9 & 3 & 6,2 & 2 & 35,82750 & 51,26348 & 1791 & E3 & PVT hw \\
\hline SA-06 & 25,0 & 2,0 & 3 & 3,5 & 2 & 35,80222 & 51,25487 & 1592 & E4 & PVT hw \\
\hline SA-08 & 20,2 & 1,6 & 3 & 1,9 & 2 & 35,78248 & 51,26123 & 1427 & E2 & PVT hw \\
\hline ST-001 & 24,5 & 2,0 & 3 & 1,6 & 2 & 35,80967 & 51,01200 & 1378 & $\mathrm{E} 1 / \mathrm{E} 2$ & NTTw hw \\
\hline ST-003 & 30,2 & 2,4 & 3 & 1,2 & 2 & 35,77400 & 51,17000 & 1543 & E1/E2 & NTTw hw \\
\hline ST-005 & 29,9 & 2,4 & 3 & 7,2 & 2 & 35,80578 & 51,34058 & 1796 & E2 & PVT hw \\
\hline ST-006 & 18,1 & 1,5 & 3 & 4,4 & 3 & 35,82689 & 51,42586 & 1804 & E1 & EDT hw \\
\hline ST-007 & 15,9 & 1,3 & 2 & 0,4 & 3 & 35,83106 & 51,63608 & 1760 & E2 & EDT hw \\
\hline ST-008 & 37,9 & 3,0 & 3 & 3,9 & 1 & 35,82864 & 51,72531 & 1919 & E3-6 & EDT hw \\
\hline ST-009 & 28,3 & 2,3 & 3 & 2,7 & 2 & 35,78742 & 51,32453 & 1680 & E1 & PVT hw \\
\hline TH-02 & 15,0 & 1,2 & 3 & 2,6 & 3 & 35,82173 & 51,40012 & 1878 & E1 & Tochal profile \\
\hline TH-03 & 22,5 & 1,8 & 3 & 0,9 & 3 & 35,88421 & 51,42013 & 3980 & E2 & Tochal profile \\
\hline TH-04 & 25,7 & 2,1 & 3 & 1,2 & 3 & 35,88268 & 51,41128 & 3768 & E2 & Tochal profile \\
\hline TH-05 & 14,5 & 1,2 & 3 & 1,3 & 3 & 35,87668 & 51,40523 & 3626 & E2 & Tochal profile \\
\hline TH-06 & 20,7 & 1,7 & 3 & 1,8 & 3 & 35,87139 & 51,40199 & 3519 & E2 & Tochal profile \\
\hline TH-07 & 19,9 & 1,6 & 3 & 6,4 & 3 & 35,86949 & 51,40401 & 3414 & E1 & Tochal profile \\
\hline TH-08 & 16,3 & 1,3 & 3 & 3,8 & 2 & 35,86574 & 51,4049 & 3200 & E1 & Tochal profile \\
\hline TH-09 & 17,9 & 1,4 & 3 & 1,0 & 2 & 35,86359 & 51,40293 & 3100 & E1 & Tochal profile \\
\hline TH-11 & 13,7 & 1,1 & 3 & 1,9 & 3 & 35,85518 & 51,3978 & 2916 & E1 & Tochal profile \\
\hline TH-12 & 14,9 & 1,4 & 3 & 3,0 & 3 & 35,83817 & 51,40749 & 2578 & E1 & Tochal profile \\
\hline TH-14 & 15,7 & 1,4 & 3 & 1,5 & 3 & 35,83325 & 51,40864 & 2410 & E1 & Tochal profile \\
\hline
\end{tabular}

${ }^{\mathrm{a}} 1=$ un-reset cooling ages; $2=$ partially reset cooling ages; $3=$ fully reset cooling ages

bw: hanging wall; fw: footwall; for fault abbreviations see text

${ }^{\mathrm{c}}$ Aliquots with recycled Cretaceous zircons

${ }^{\mathrm{d}}$ Samples collected at the top of the Karaj Formation

elevation (Figures 4 and 5b; Table 2). The uppermost 5 samples $(\sim 3.4-4 \mathrm{~km})$ exhibit cooling ages ranging from $16.2 \pm 0.8$ to $13.8 \pm 0.7 \mathrm{Ma}$, while samples collected at an elevation of 3.4 to $2.6 \mathrm{~km}$ have cooling ages of $12.1 \pm 0.6$ to $11.2 \pm 0.6 \mathrm{Ma}$. The lowermost 3 samples $(\sim 1.8-2.5 \mathrm{~km}$ of elevation), have cooling ages varying from $9.2 \pm 0.5$ to $8.1 \pm 0.4 \mathrm{Ma}$ (Figure 4 ). The AHe ages of samples collected outside of the vertical transect vary between $3.6 \pm 0.2$ and $12.5 \pm 0.7 \mathrm{Ma}$, except for one sample located in the footwall of the duplex system, which yields a cooling age of $36.3 \pm 0.2 \mathrm{Ma}$ (Figure 5b). Along the trace of the NTT, AHe cooling ages are quite uniform $(\sim 7-6 \mathrm{Ma})$, even across the major frontal ramps of the transpressional duplex where the $\mathrm{ZHe}$ ages are clearly offset; the cooling ages are also uniform toward the NTT tips, where they tend to increase to $\sim 8-9 \mathrm{Ma}$ (Figure 5). AHe ages in that area also do not strongly correlate with elevation, as observed for the $\mathrm{ZHe}$ data (Figure $7 \mathrm{~b}$ ), or with stratigraphic position (Figure 6). Instead, there is a cluster of AHe ages at $\sim 7-6 \mathrm{Ma}$ at elevations ranging from 1.4 to $1.8 \mathrm{~km}$ (Figure $7 \mathrm{~b}$ ). Finally, previously determined AHe data from the transpressional duplex (two samples; Figure 6b) and immediately north of it (five samples, see figure 7 of Guest et al. [2006b]) vary between 4 and $7 \mathrm{Ma}$, and thus seem to be coeval with or slightly younger (1 to 3 m.y.) than samples collected along the NTT in proximity to the mountain front.

\section{Interpretation}

\subsection{Zircon (U-Th)/He Cooling Ages}

[15] The age-elevation relationships of the Tochal vertical transect (Figure 4) are consistent with published vertical profiles [e.g., Stockli et al., 2000, 2002, 2003] and borehole data [e.g., House et al., 1999; Stockli and Farley, 2004; Wolfe and Stockli, 2010]. The inflection point in the age profile at about 18-14 Ma marks the base of the zircon partial retention zone (ZPRZ), with samples above it reflecting partially reset cooling ages, and samples below it representing fully reset cooling ages. The reset ages record the onset of accelerated rock uplift and fast cooling below the $\mathrm{ZHe}$ closure temperature (Figure 4). Because the depositional age of the volcaniclastic Karaj Formation is 55-50 to $36 \mathrm{Ma}$ [Ballato et al., 2011; Verdel et al., 2011], and accelerated exhumation started at $\sim 18-14 \mathrm{Ma}$, we can divide the ZHe cooling ages obtained from samples outside the vertical profile into three different age groups (Figures 5a and 7; Table 1). These age groups include 1) 34-47 Ma (7 samples; un-reset ages); 2) 20-30 Ma (10 samples; partially reset ages); and 3) 16-18 Ma (2 samples; fully reset ages).

[16] ZHe cooling ages of the first group (34-47 Ma) are interpreted to reflect volcanic cooling, and to a first approximation, they represent the sediment depositional ages. These un-reset ages imply that the magnitude of exhumation 
Table 2. Summary of Apatite (U-Th)/He Cooling Ages

\begin{tabular}{|c|c|c|c|c|c|c|c|c|c|}
\hline Sample & Age [Ma] & $\pm[\mathrm{Ma}]$ & Aliquotes & $\mathrm{SD}$ & Latitude $\left(^{\circ}\right)$ & Longitude $\left(^{\circ}\right)$ & Elevation (m) & Unit & Structural location \\
\hline TH08-05 & 3,6 & 0,2 & 3 & 0,3 & 35,94312 & 51,53752 & 2002 & E undiff. & MF hw \\
\hline TH08-07 & 7,8 & 0,5 & 3 & 0,8 & 35,82664 & 51,17648 & 2184 & E2 & PVT hw \\
\hline TH08-08 & 10,8 & 0,6 & 3 & 0,8 & 35,81436 & 51,17620 & 1969 & E4 & NTTw hw \\
\hline TH08-10 & 9,6 & 0,6 & 3 & 2,0 & 35,78784 & 51,15915 & 1636 & E2 & NTTw hw \\
\hline TH08-12 & 6,7 & 0,3 & 3 & 0,4 & 35,87170 & 51,04788 & 1471 & E4 & NTT hw \\
\hline TH08-13 & 9,5 & 0,6 & 3 & 1,5 & 35,84421 & 51,05709 & 1425 & E2/E3 & NTTw hw \\
\hline TH08-14 & 6,8 & 0,4 & 5 & 1,6 & 35,79534 & 51,03817 & 1530 & E1 & NTT hw \\
\hline TH08-22 & 12,5 & 0,7 & 3 & 0,7 & 35,81032 & 51,82980 & 2310 & Intrusive & MF hw \\
\hline TH08-24 & 36,3 & 2,2 & 3 & 4,5 & 35,75801 & 51,69988 & 1510 & E undiff. ${ }^{b}$ & MF fw \\
\hline SA-02 & 12,0 & 0,6 & 3 & 1,9 & 35,79675 & 51,03983 & 1569 & E3 & PVT hw \\
\hline SA-03 & 9,5 & 0,6 & 3 & 0,8 & 35,77400 & 51,17000 & 1543 & E4 & PVT hw \\
\hline SA-05 & 10,7 & 0,6 & 3 & 0,2 & 35,82750 & 51,26348 & 1791 & E3 & PVT hw \\
\hline SA-06 & 7,8 & 0,5 & 3 & 0,3 & 35,80222 & 51,25487 & 1592 & E4 & PVT hw \\
\hline SA-08 & 6,4 & 0,4 & 2 & 0,5 & 35,78248 & 51,26123 & 1427 & E2 & PVT fw \\
\hline ST-001 & 8,7 & 0,5 & 2 & 0,8 & 35,80967 & 51,01200 & 1378 & E1/E2 & NTTw hw \\
\hline ST-003 & 4,2 & 0,3 & 3 & 0,8 & 35,77400 & 51,17000 & 1543 & E1/E2 & NTTw hw \\
\hline ST-005 & 6,6 & 0,4 & 1 & - & 35,80578 & 51,34058 & 1796 & E2 & PVT hw \\
\hline ST-006 & 6,0 & 0,4 & 3 & 1,4 & 35,82689 & 51,42586 & 1804 & E1 & EDT hw \\
\hline ST-008 & 8,3 & 0,5 & 3 & 1,1 & 35,82864 & 51,72531 & 1919 & E3-6 & EDT hw \\
\hline ST-009 & 6,4 & 0,4 & 1 & - & 35,78742 & 51,32453 & 1680 & E1 & PVT hw \\
\hline $270505-1$ & 6,4 & 0,4 & 2 & 0,8 & 35,83436 & 51,66553 & 1813 & Intrusive & MF hw \\
\hline 310505-01 & 8,6 & 0,3 & 2 & 3,2 & 35,83878 & 51,78511 & 2822 & Intrusive & MF hw \\
\hline $310505-02$ & 10,5 & 0,6 & 3 & 1,0 & 35,83750 & 51,78375 & 2688 & Intrusive & MF hw \\
\hline TH-02 & 8,1 & 0,4 & 3 & 0,5 & 35,82173 & 51,40012 & 1878 & E1 & Tochal profile \\
\hline TH-03 & 15,0 & 0,7 & 3 & 1,5 & 35,88421 & 51,42013 & 3980 & E2 & Tochal profile \\
\hline TH-04 & 15,5 & 0,8 & 3 & 3,1 & 35,88268 & 51,41128 & 3768 & E2 & Tochal profile \\
\hline TH-05 & 15,9 & 0,8 & 3 & 2,0 & 35,87668 & 51,40523 & 3626 & E2 & Tochal profile \\
\hline TH-06 & 16,2 & 0,8 & 3 & 2,7 & 35,87139 & 51,40199 & 3519 & E2 & Tochal profile \\
\hline TH-07 & 13,8 & 0,7 & 3 & 5,5 & 35,86949 & 51,40401 & 3414 & E1 & Tochal profile \\
\hline TH-10 & 12,1 & 0,6 & 3 & 0,9 & 35,85856 & 51,39988 & 2952 & E1 & Tochal profile \\
\hline TH-11 & 11,2 & 0,6 & 3 & 1,5 & 35,85518 & 51,3978 & 2916 & E1 & Tochal profile \\
\hline TH-12 & 8,2 & 0,4 & 3 & 1,3 & 35,83817 & 51,40749 & 2578 & E1 & Tochal profile \\
\hline TH-14 & 9,2 & 0,5 & 3 & 1,1 & 35,83325 & 51,40864 & 2410 & E1 & Tochal profile \\
\hline
\end{tabular}

${ }^{\mathrm{a}} \mathrm{Hw}$, hanging wall; fw, footwall; for fault abbreviations see text

${ }^{\mathrm{b}} \mathrm{Samples}$ collected at the top of the Karaj Formation

in some sectors of the duplex was insufficient to exhume rocks from depths corresponding to a temperature field of $>130^{\circ} \mathrm{C}$ (top of the ZPRZ). Two samples from the top of the Karaj Formation yield ages of $39.3 \pm 3.1$ (EDT hanging wall) and $38.3 \pm 3.1$ (NTT footwall) Ma (Figure 5a). These ages correspond to the termination of the Eocene back-arc magmatism at $\sim 36 \mathrm{Ma}$ in this region [Ballato et al., 2011; Verdel et al., 2011], corroborating our interpretation that group 1 ages represent un-reset cooling ages. Along these lines, we interpret the two aliquots yielding cooling ages older than the depositional age $(70.4 \pm 5.6$ and $84.9 \pm 6.8 \mathrm{Ma})$ as recycled detrital zircons, either sourced from the Cretaceous magmatic arc or from tectonically cooled areas, located along the southern margin of the Eurasian plate [e.g., Agard et al., 2011].

[17] In light of the results from the Tochal vertical profile (Figure 4), the distribution of the zircon cooling ages with respect to stratigraphic position (Figure 6), and the sampling elevation (Figure 7a), we interpret data of group 2 (20-30 Ma) as partially reset cooling ages. This implies that the samples resided within the ZPRZ for a long time where ${ }^{4} \mathrm{He}$ diffusion processes dominated on time scales $>10^{6}$ years. These samples, located in proximity to the PVT and NTTw and within the EDT hanging wall, represent the exhumed fossil ZPRZ (Figures 5a and 6).

[18] Finally, we interpret cooling ages of group 3 (16-18 Ma) as fully reset ages on the EDT fault block, in agreement with the age-elevation plot of the Tochal vertical profile. These younger cooling ages record the onset of accelerated thrusting and associated surface uplift and exhumation along the EDT during the Middle Miocene. Importantly, this interpretation is in agreement with the subsidence history and sedimentation patterns documented in the Miocene foreland basin of the southern Alborz mountains [Ballato et al., 2008], and with the presence of Late Oligocene-Early Miocene foreland-basin deposits preserved in the hanging wall of the EDT [Ballato et al., 2011]. These reset ages imply that fault slip along the EDT must have been enough to exhume rocks from below the ZPRZ.

\subsection{Apatite (U-Th)/He Cooling Ages}

[19] The apatite age-elevation plot of the Tochal vertical transect (Figure 4a) appears to have a double kink characterized by three distinct segments. AHe ages at higher elevations (first segment) are similar to $\mathrm{ZHe}$ ages from the base of the vertical profile and thus are interpreted to record the same pulses of rock uplift associated with fast cooling and exhumation at $\sim 18-14 \mathrm{Ma}$ (Figure $4 \mathrm{~b}$ ). The younger ages at the base of the profile (third segment) reveal a second pulse of fast exhumation that affected the mountain front in proximity to the EDT at 9.5-7.5 Ma (Figure 6b). Between these two pulses of fast exhumation, the intermediate segment records slower exhumation rates. Alternatively, if the lowest and the 
BALLATO ET AL.: COLLISIONAL OBLIQUE STRAIN
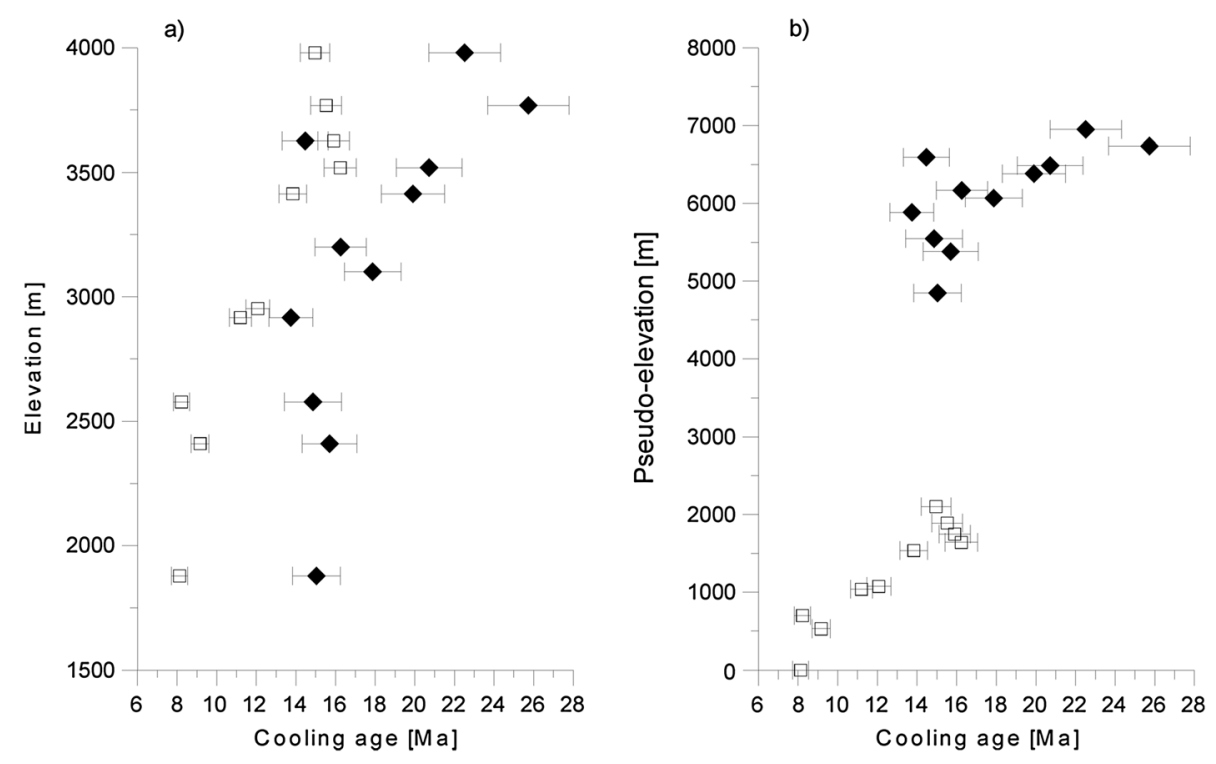

Figure 4. (a) Age-elevation relationship showing zircon and apatite (U-Th)/He cooling ages along the Tochal profile. (b) Stacked pseudo-vertical transect [Reiners and Brandon, 2006]. AHe data are plotted with respect to the lowermost sample assumed to be located at $0 \mathrm{~km}$ of structural depth, and ZHe data are offset upward from their relative elevations by a height equal to the difference in the closing depth of the two systems. According to the parameters discussed in section 6.3 this difference is estimated to be $4.85 \pm 0.97 \mathrm{~km}$. Both plots highlight a distinct break in slope at $\sim 18-14 \mathrm{Ma}$ for the zircon-age profile, and possibly a double kink age-elevation relationship with enhanced exhumation at $\sim 18-14$ and 9.5-7.5 Ma for the AHe-age profiles.

highest samples were considered to be poorly representative due to local thermal effects, strong U-zonation, presence of small inclusions undetectable with optic microscopy, local splay faulting, drag folding, etc., the age-elevation profile could be approximated with a linear trend. This would suggest steady exhumation rates since the Middle Miocene. However, considering that previous studies documented punctuated collision-related deformation across the Alborz mountains [Axen et al., 2001; Guest et al., 2006b, 2007; Ballato et al., 2008, 2011; Rezaeian et al., 2012], we favor the double kink interpretation with two pulses of rapid exhumation at $\sim 18-14 \mathrm{Ma}$ and $\sim 9.5-7.5 \mathrm{Ma}$.

[20] The relatively good control on the depositional age of the analyzed samples indicates that all of our AHe ages are fully reset cooling ages. Exhumation must therefore have involved rocks from a depth corresponding to temperatures in excess of $60-80^{\circ} \mathrm{C}$, even for samples with un-reset to partially reset $\mathrm{ZHe}$ ages. The exception, however, is one sample collected in the footwall of the duplex system on top of the Karaj Formation (Figure 5b), which yielded similar $\mathrm{AHe}(\sim 36 \mathrm{Ma})$ and $\mathrm{ZHe}(38.3 \pm 3.1 \mathrm{Ma})$ cooling ages, and thus are associated with the termination of arc magmatism [Ballato et al., 2011; Verdel et al., 2011]. Hence, in the corresponding sector of the foreland, there was not sufficient sediment burial after the deposition of the Karaj Formation to reset the AHe system. Finally, the uniform cooling ages of $\sim 7-6 \mathrm{Ma}$ along the NTT suggests that there might have been a third pulse of rapid exhumation, which was most likely associated with a change in deformation style (see section 6.2). This third pulse apparently predates an increase in exhumation recorded at $\sim 5 \mathrm{Ma}$ in the interior of the orogen [Axen et al., 2001; Guest et al., 2006b; Rezaeian et al., 2012].

\section{Discussion}

[21] The new ZHe and AHe thermochronometry allows us to document the deformation and exhumation history of the North Tehran Transpressional Duplex at high temporal resolution. Structural analysis indicates that a poorly dated change from NW- to a NE-oriented shortening must have occurred in the Alborz mountains [Axen et al., 2001; Zanchi et al., 2006; Guest et al., 2006a; Landgraf et al., 2009; Ballato et al., 2011]. Prior to our study, the best time constraint for this changeover was that it occurred before $\sim 8-6 \mathrm{Ma}$, based on cross-cutting relationships observed in the interior of the Alborz mountains [Axen et al., 2001]. This is compatible with the evolution of the southern Alborz mountains, where the older NW-oriented shortening regime must have been active prior to $\sim 9 \mathrm{Ma}$ [Ballato et al., 2011]. The lower bound for the kinematic changeover is $\sim 36 \mathrm{Ma}$, the age of the top of the Karaj Formation [Ballato et al., 2011], which is the youngest unit showing unambiguous deformation during the older regime. In the context of these observations and our new $\mathrm{ZHe}$ ages that are offset by $\mathrm{NW}$-striking thrusts, we conclude that most of the rock uplift and exhumation associated with tectonic activity of the transpressional duplex was accomplished after the changeover of the shortening direction from NW- to NE. If correct, the older shortening regime should have been active prior to $18 \mathrm{Ma}$. We infer that the older, NW-oriented shortening regime has not been associated with significant uplift and exhumation across the thrust sheets in this area. The NE-striking folds, which are exposed only on the NTTw and PVT, far from the southern mountain front (NTT), are closely spaced (up to $10 \mathrm{~km}$ ), have relatively low amplitudes, and do not record any evidence of faulting. These 

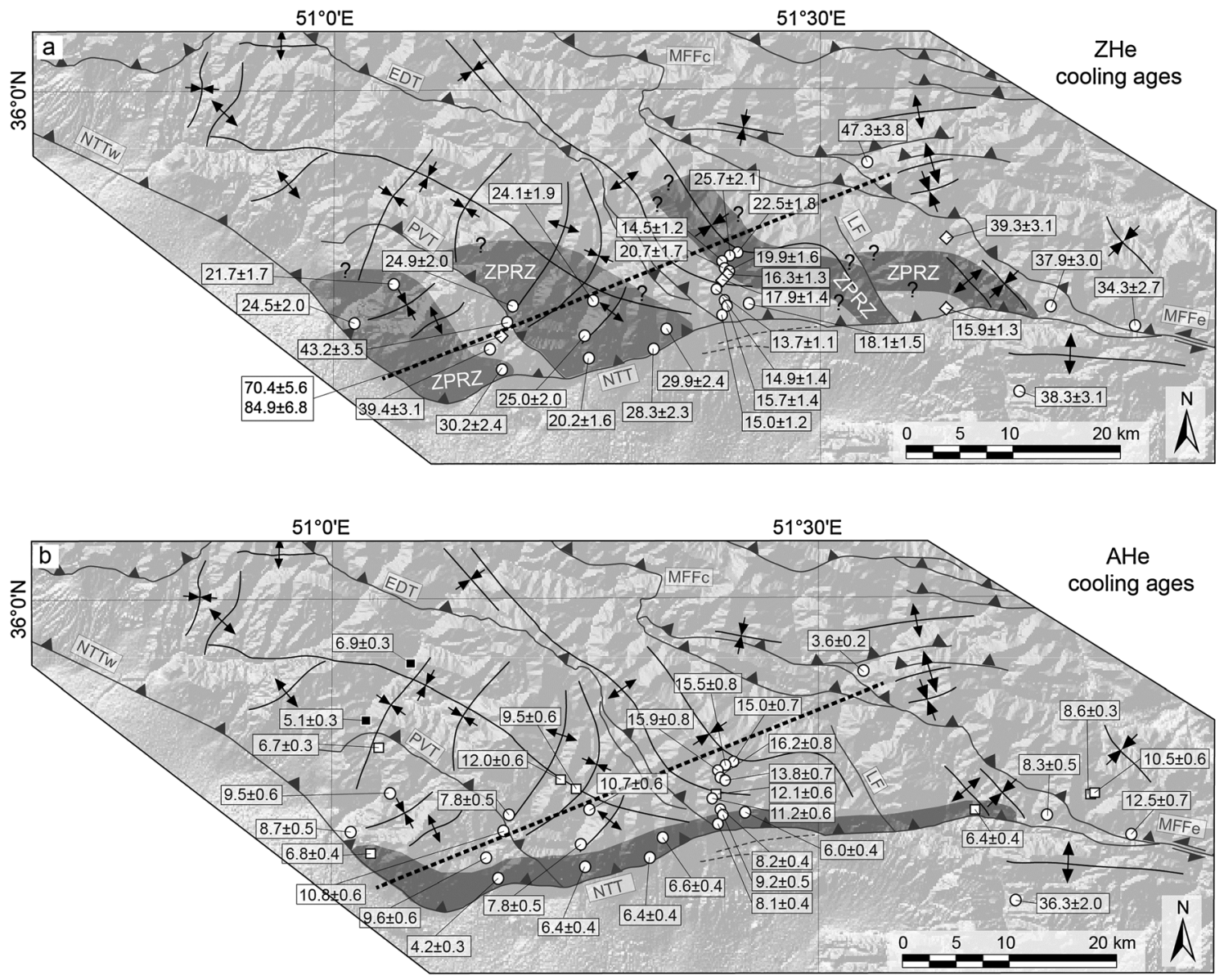

Figure 5. (a) Zircon He and (b) apatite He cooling ages plotted on a structural map based on a DEM. The dark grey area in figure a highlights the fossil zircon partial retention zone (ZPRZ), which is repeated across the NW-striking frontal ramps of the duplex system, while the gray area in figure b highlights the distribution of the uniform 7-6 Ma cooling ages along the NTT.

observations suggest that these structures were associated with relatively shallow detachments, with consequent limited exhumation. In the following sections, we discuss the significance of these results for unraveling long-term transpressional continental collision processes in the orogenic evolution of the greater Alborz region.

\subsection{Early stage (18-14 Ma) Transpressional Duplex Development}

[22] Zircon (U-Th)/He thermochronometry records the time since cooling below an effective closure temperature of $\sim 180^{\circ} \mathrm{C}$, assuming typical crystal size and orogenic cooling rates [e.g. Reiners and Brandon, 2006]. This thermal threshold is associated with a 130 to $200{ }^{\circ} \mathrm{C}$ ZPRZ, where some proportion of ${ }^{4} \mathrm{He}$ resulting from the $\alpha$-decay of parent isotopes diffuses out of the crystal lattice. Given that the $\sim 70^{\circ} \mathrm{C}$ temperature window of the ZPRZ corresponds to a crustal thickness of 3.1 to $2.5 \mathrm{~km}$, assuming a geothermal gradient of $25 \pm 2.5^{\circ} \mathrm{C} / \mathrm{km}$, exposures of the fossil ZPRZ may provide useful thermal-stratigraphic markers to investigate exhumation patterns, exhumation magnitude, and the paleogeothermal structure of the crust where at least 5 to $6 \mathrm{~km}$ of exhumation has occurred.

[23] We combined published structural observations (Allen et al., 2003; Guest et al., 2006a; Zanchi et al., 2006; Landgraf et al., 2009) (Figure 2), available stratigraphic data (Figure 6), and our new ZHe cooling ages (Figure 5) to construct a simplified cross-section of the North Tehran Transpressional Duplex (Figure 8) to help decipher its structural and thermal evolution. To match the different data sets, we infer a ramp-flat geometry for the NTTw and PVT thrust sheets. These thrust sheets consist of a gently-dipping master décollement at the base of the Lower Shale (E1) of the Karaj Formation at a depth of about $6-7 \mathrm{~km}$, associated with surface-breaking northdipping ramps with a range of dip angles (Figure 8). This geometry agrees with the regional structural model proposed by Guest et al. [2006a]. Stratigraphy across the transpressional duplex is highly heterogeneous, with rapid sedimentary facies changes and variable stratal thickness (Figure 6). In particular, the sedimentary strata in the hanging wall of the EDT are dominated by the Lower Shale (E1) and the Middle Tuff (E2) members (with at least $4.5 \mathrm{~km}$ of thickness), while the middle to upper part of the Karaj Formation is approximately $2 \mathrm{~km}$ thick (E3 to E6; Figure 6). Conversely, the strata comprising the footwall of the EDT (E1 to E6) have a minimum thickness of $5.5 \mathrm{~km}$ and are generally coarser grained (Figure 6). The significant difference in sedimentary facies and stratal thickness across the EDT suggests that this structure was related to the earliest phase of Eocene back-arc extension (E1 deposition). Similar to other formerly 


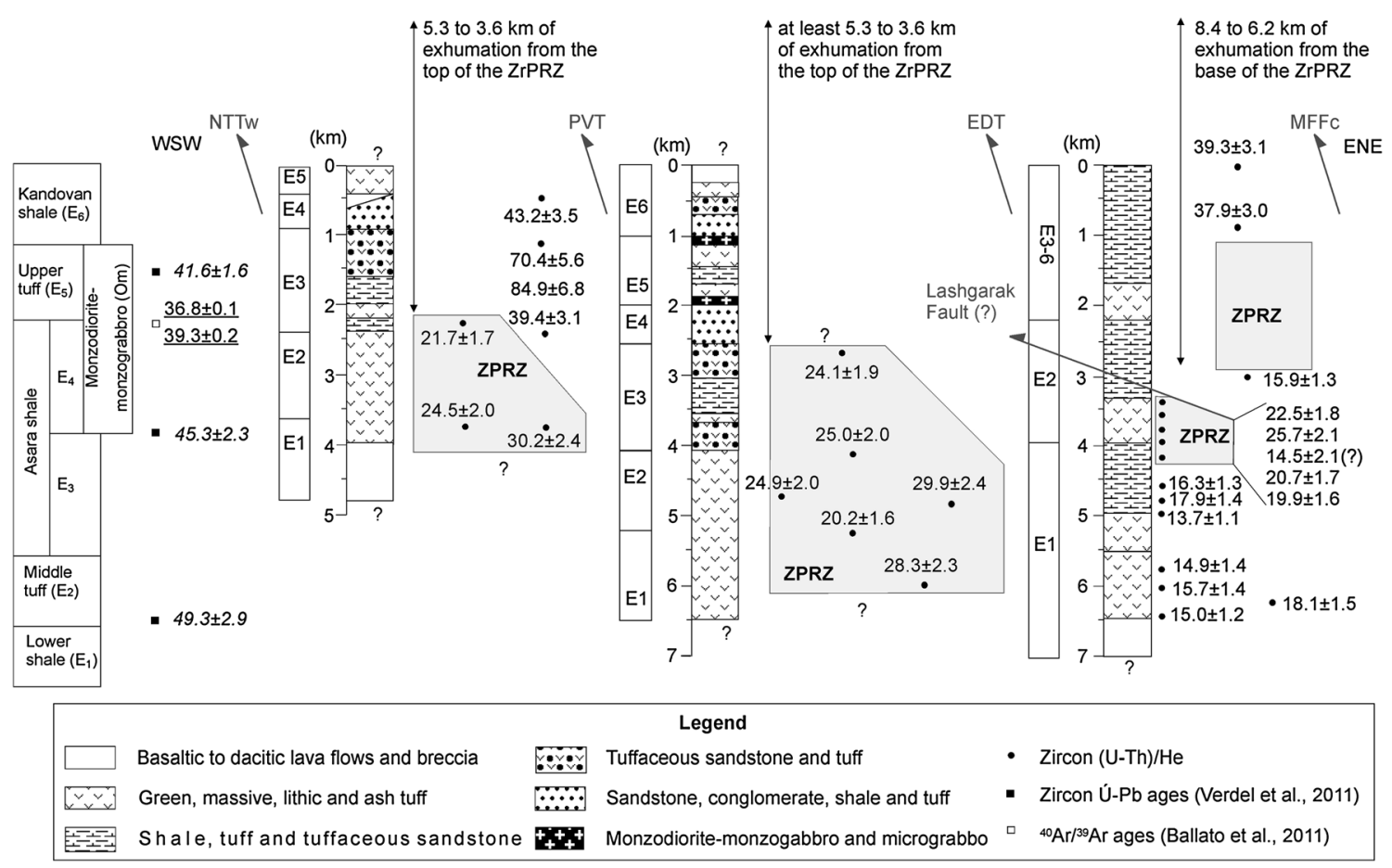

Figure 6. Simplified stratigraphic sections for the Karaj Formation in different thrust sheets of the transpressional duplex, including ZHe cooling ages and the location of fossil ZPRZ (grey transparent areas). Stratigraphy from Amini et al. [1993]. The stratigraphic sections are aligned with respect to the topmost strata of Karaj Formation. The stratigraphic top of the Karaj Formation is preserved only in the EDT hanging wall, where it is overlain by at least $640 \mathrm{~m}$ of Oligo-Miocene red beds [Ballato et al., 2011]. Elsewhere, the top of the Karaj Formation as well as the Oligo-Miocene red beds have been eroded and thus the depth values represent minimum estimations.
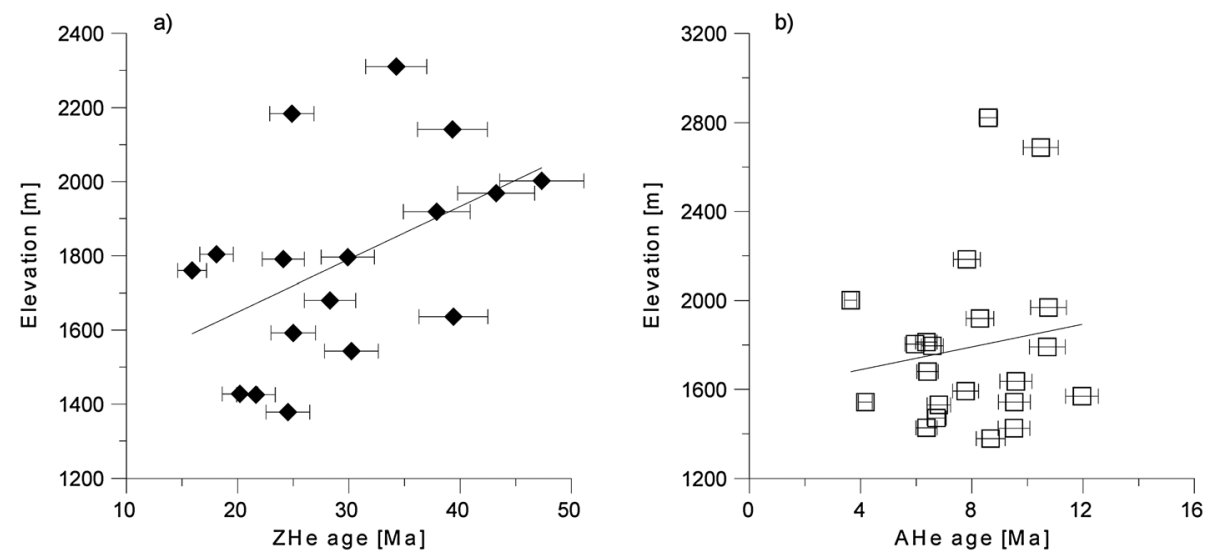

Figure 7. Age-elevation relationship showing (a) ZHe and (b) AHe cooling ages for the samples collected across the duplex (excluding the Tochal vertical profile). The un-reset cooling ages from the sample collected in the footwall of the NTT (top of Karaj Formation, ZHe and AHe of $38.3 \pm 3.1$ and $36.3 \pm 2.2 \mathrm{Ma}$, respectively) and from the sample yielding Cretaceous ZHe cooling ages in the hanging wall of the PVT $(70.4 \pm 5.6$ and $84.9 \pm 6.8 \mathrm{Ma})$ were not plotted. ZHe data exhibit a positive correlation with elevation $\left(\mathrm{R}^{2}=0.23\right)$, while AHe data do not present any clear linear trend $\left(\mathrm{R}^{2}=0.02\right)$.

extensional settings [e.g., Mora et al., 2006; Hain et al., 2011], this structure was reactivated during Miocene contraction. Tectonic inversion is in agreement with previous studies that documented or inferred the existence of inherited, primarily E-W striking structures in the Alborz range [Zanchi et al., 2006; Yassaghi and Madanipour, 2008; Yassaghi and Naeimi,
2011]. Therefore, the E-W-striking NTT, which presently bounds the southern Alborz mountain front, may also represent a reactivated inherited structure.

[24] Importantly, our thermochronologic data show a half U-shaped age-distance relationship with respect to the frontal ramps [e.g., Lock and Willett, 2008] (Figure 8a), revealing 


\section{BALLATO ET AL.: COLLISIONAL OBLIQUE STRAIN}
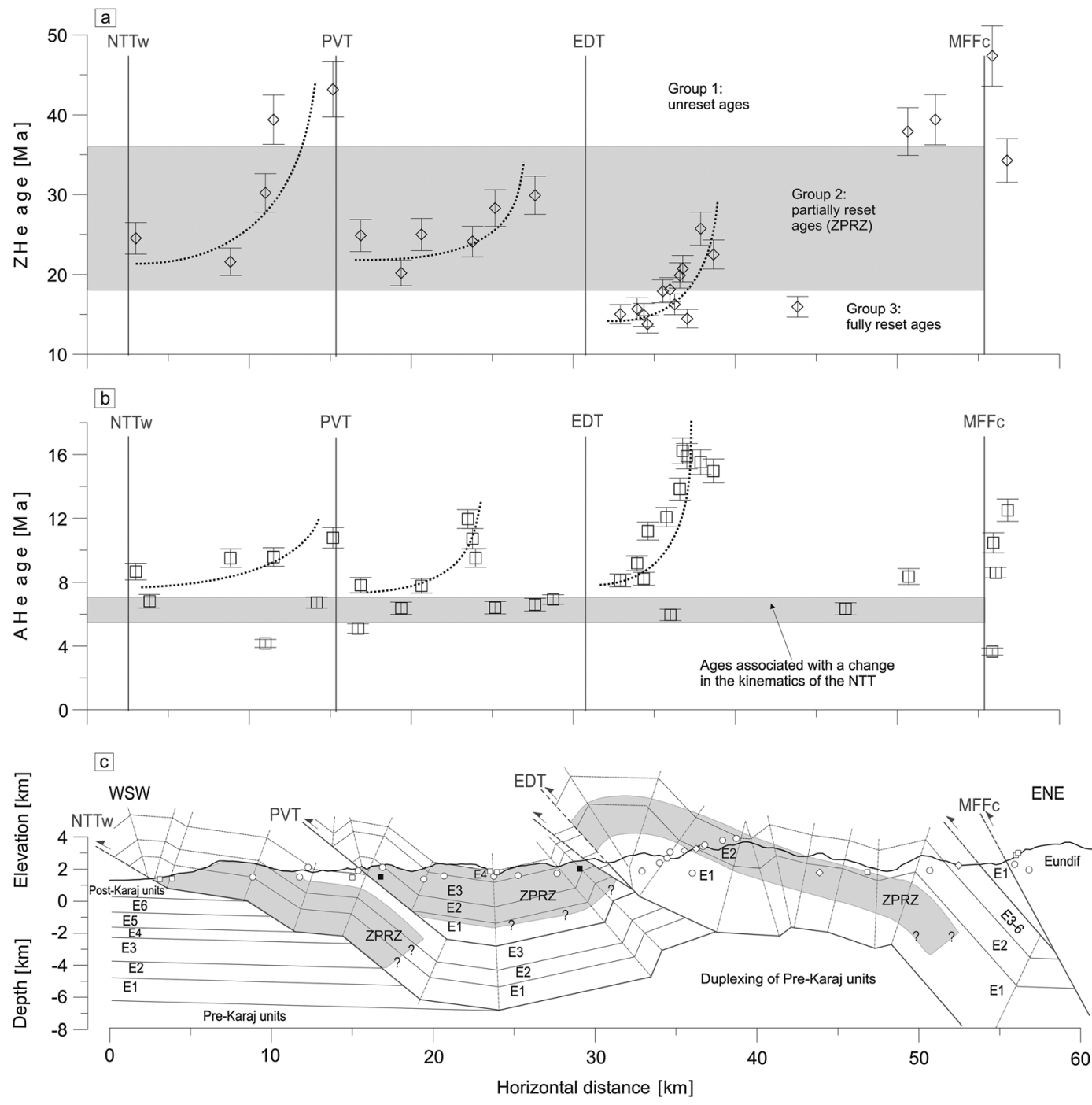

Figure 8. (a) ZHe and (b) AHe cooling ages projected onto the trace of the geologic cross section shown in figure 2 (the angle between the projected samples and the cross section is $\sim 70^{\circ}$ for the the NTTw and PVT thrust sheets, and ca $50^{\circ}$ for the EDT and MFc thrust sheets). The two ZHe Cretaceous cooling ages are not plotted. The grey area of A highlights the location of the fossil ZPRZ, while the grey area of B shows uniform $\sim 7-6 \mathrm{Ma}$ AHe cooling ages along the NTT. Cooling ages decrease in proximity to the principal frontal ramps according to the half U-shaped pattern. (c) Simplified geologic cross section across the North Tehran Thrust Transpressional Duplex showing the structural repetition of the ZPRZ. The samples are projected onto the topographic profile according to the symbols of Figure 3.

an en-échelon map pattern of a fossil ZPRZ that is systematically repeated across the major frontal ramps of the transpressional duplex (Figures 5a and 8). Fully reset ZHe ages in the hanging wall of the EDT imply that the detachment reached its greatest depth corresponding to temperatures $200^{\circ} \mathrm{C}$. Concerning the NTTw and PVT, the position of the décollement must have been at temperatures between 200 and $130^{\circ} \mathrm{C}$, because only rocks with partially reset and un-reset ZHe cooling ages are exposed (Figure 8).

[25] The fully reset ZHe age of $15.9 \pm 1.3 \mathrm{Ma}$ is located at great distance from the EDT trace $(\sim 25 \mathrm{~km}$; Figure $5 \mathrm{a})$ and belongs to a sample of the upper part of unit E2 (Figure 6). In contrast, fully reset ages in the Tochal vertical profile are proximal to the major frontal ramp, and are entirely contained within unit E1 (Figures 5a and 8). To explain this difference we infer the presence of a thrust fault within unit
E2 (here informally called Lashgarak Fault; Figures 2, 4a, and 5), along a valley where highly cataclasized volcanics are exposed. Such a fault is expected to double unit E2 and to offset the fossil ZPRZ. The lack of samples along the NTT between the two ages of group 3, however, limits a further assessment of the fossil ZPRZ in that area.

[26] The thickness estimates of the ZPRZ (Figures 6 and 8) are based on the assumption that the isotherms at depth are flat and the geothermal gradient is constant through time. These conditions, however, represent an oversimplification given that erosion will cause an upward advection of heat with isotherm migration, geothermal gradient increase, and ultimately a variation in the size of the PRZs [e.g., Stuwe et al., 1994: Moore and England, 2001; Ehlers, 2005]. The thermal structure of the upper crust in a fold-and-thrust belt depends on the depth to detachment, fault-slip rate, and thrust-ramp 
angle [Lock and Willett, 2008]. A longer thrust ramp, a deeper detachment, and a higher slip rate will cause greater heat advection, leading to shallower and compressed isotherms and consequently a shallower and thinner PRZ. This seems to be the case for the EDT, where a deeper detachment and faster exhumation might have produced a shallower and thinner fossil ZPRZ (Figures 5a, 6, and 8).

[27] Overall, the combination of different factors, such as depth of the décollement with respect to the closure temperature of the ZHe system, the regional thermal structure before and during contractional deformation, fault spacing, fault-dip angle, and the amount of slip along the principal frontal ramps, leads to a complex distribution of $\mathrm{ZHe}$ ages across the entire transpressional duplex.

\subsection{Late stage (10-6 Ma) Transpressional Duplex Development}

[28] The AHe data distribution in the interior of the North Teheran Transpressional Duplex is characterized by a 2 to 3 m.y. step in the cooling ages across the major frontal ramps (PVT and EDT) (Figures 5b and 8). This age difference is not as pronounced as the one recorded by the $\mathrm{ZHe}$ data, because all AHe ages are fully reset, and most of them experienced accelerated cooling during the last 4-10 Ma.

[29] Regarding the timing of exhumation revealed by our AHe data along the Tochal vertical profile (Figure 4), we suggest that increased rock-uplift rates occurred from 9.5-7.5 Ma. According to the half U-shaped cooling pattern of AHe data (Figure 8a), this second pulse in rock uplift seems to have occurred during kinematic conditions similar to those that dominated faulting during the $\sim 18-14$ Ma deformation event. This pulse is coeval with the southward propagation of the deformation front in the southern Alborz mountains, which caused the incorporation of the Miocene foreland-basin system into the orogenic wedge [Ballato et al., 2008], suggesting along-strike continuity in the timing of orogenic processes.

[30] AHe data along the NTT fault trace exhibit uniform cooling ages of $\sim 7-6 \mathrm{Ma}$ at elevations ranging from ca. 1.4 to $1.8 \mathrm{~km}$ and across the major NW-striking frontal ramps of the transpressional duplex (Figures 5a and 8a; Table 2). This uniform AHe age pattern contrasts with an expected increase in ages with distance from the frontal ramps and with elevation if the kinematic regime were characterized by SW-directed thrusting along the NW-striking frontal ramps. In contrast, the $\mathrm{ZHe}$ ages from the same samples do show variations with distance from the ramps and with elevation (Figures 5a and 8a). Based on these observations, we suggest that starting from $\sim 7-6 \mathrm{Ma}$, the semi-independent segments forming the former lateral to oblique ramp of the NTT were reactivated as a single, throughgoing master thrust fault (Figure 9). This interpretation implies that the transpressional duplex did not accommodate significant oblique shortening across the NW-striking frontal ramps during the last 7-6 Ma, but rather N-S- or NNE-SSW-directed shortening through thrusting along the NTT.

[31] The kinematic changeover of the NTT is also corroborated by fault kinematic data [Zanchi et al., 2006; Landgraf et al., 2009], and agrees with geomorphic observations along the NTT and the Tehran plain [Abbassi and Farbod, 2009; Landgraf et al., 2009]. There, southward thrusting along an E-W striking shallow-dipping thrust, most likely representing splay faults of the NTT (Figure 3a), as well as northward thrusting, is coupled with left-lateral strike-slip faulting along sub-vertical faults [Abbassi and Farbod, 2009; Landgraf et al., 2009]. Although the onset of deformation in the southern foreland basin has not been rigorously dated, stratigraphic relationships suggest that it should be younger than $5 \mathrm{Ma}$ [Rieben, 1955]. This is in agreement with the kinematic change of the NTT at approximately $7 \mathrm{Ma}$. Alternatively, if the onset of deformation in the Tehran plain were younger than $7 \mathrm{Ma}$, the left-lateral component induced by neotectonic NNE-directed shortening could have been accommodated in the range interior [Ritz et al., 2006; Guest et al., 2006a] or along the northern margin of the orogen [Ghassemi, 2005].

[32] The changeover in kinematics of the NTT raises a major question concerning the overall style of deformation in the Alborz mountains. The dip-slip motion across the E-W striking NTT does not seem to be associated with any macro-scale refolding of the hanging-wall structures. If enough fault slip and erosion have occurred along the steeply $\left(60^{\circ}\right)$ dipping NTT, any existing fold hinges could have been completely removed by erosion and only the back limb of the fold will be exposed.

\subsection{Quantification of Long-term Exhumation and Uplift}

[33] Surface uplift is equal to rock uplift minus exhumation [e.g., Molnar and England, 1990]. To estimate the magnitude of rock uplift and exhumation associated with thrusting along the frontal ramps of the transpressional duplex, we use exhumed levels of the partial retention zones as temperaturespecific marker levels. We assume a mean and flat geothermal gradient of $25 \pm 2.5^{\circ} \mathrm{C}$ [e.g., Chapman, 1986], and a mean surface paleo-temperature of $\sim 20 \pm 2{ }^{\circ} \mathrm{C}$, considering that the present mean annual temperature in Tehran is $\sim 17^{\circ} \mathrm{C}$ (http://nds.121.iaea.org/wiser/) and that the Middle Miocene was warmer than today [e.g., Zachos et al., 2001]. For the ZHe data (18-14 Ma pulse), we consider a basin paleoelevation of $0.15 \pm 0.15 \mathrm{~km}$. Because a marine transgression across Iran deposited sediments between the Late Oligocene and the Early Miocene, the basin paleo-surface is inferred to have been approximately at sea level at that time [Reuter et al., 2009]. For the AHe data ( 7-6 Ma pulse of deformation), we assume a mean average elevation of the paleo-mountain front of $0.6-1.2 \mathrm{~km}$. This corresponds to an intermediate value between the modern elevation of $1.4-1.8 \mathrm{~km}$ and an inferred paleo-elevation of $0.15 \pm 0.15 \mathrm{~km}$ for the area, before the onset of deformation at $18-14 \mathrm{Ma}$. The reference frame is the present-day sea level, which is most likely similar to the Middle Miocene level [e.g., Miller et al., 2005].

[34] For the EDT thrust sheet we use the base of the fossil ZPRZ as a marker level $\left(\sim 200^{\circ} \mathrm{C}\right)$, which was uplifted to an elevation of about $3 \mathrm{~km}$ along the Tochal vertical profile. Based on these considerations we can calculate a paleo-depth for the base of the ZPRZ of 8.1 to $6.2 \mathrm{~km}$ with respect to sea level $\left(200^{\circ} \mathrm{C}\right.$ minus $20 \pm 2{ }^{\circ} \mathrm{C}$ divided $25 \pm 2.5^{\circ} \mathrm{C}$ minus $0.15 \pm 0.15 \mathrm{~km})$. This results in a total rock uplift of 11.1 to $9.2 \mathrm{~km}$ (paleo-depth of the ZPRZ plus modern elevation), which amounts to a long-term rock uplift rate (averaged over $18-14 \mathrm{m.y}$.) of $0.51-0.74 \mathrm{~mm} / \mathrm{yr}$, and surface uplift of 3 to $2.7 \mathrm{~km}$ (present-day elevation of the base of the fossil ZPRZ minus basin paleo-elevation). This implies that exhumation on the EDT fault block is up to 8.4 to $6.2 \mathrm{~km}$ with respect to the base of the ZPRZ, corresponding to a long-term 


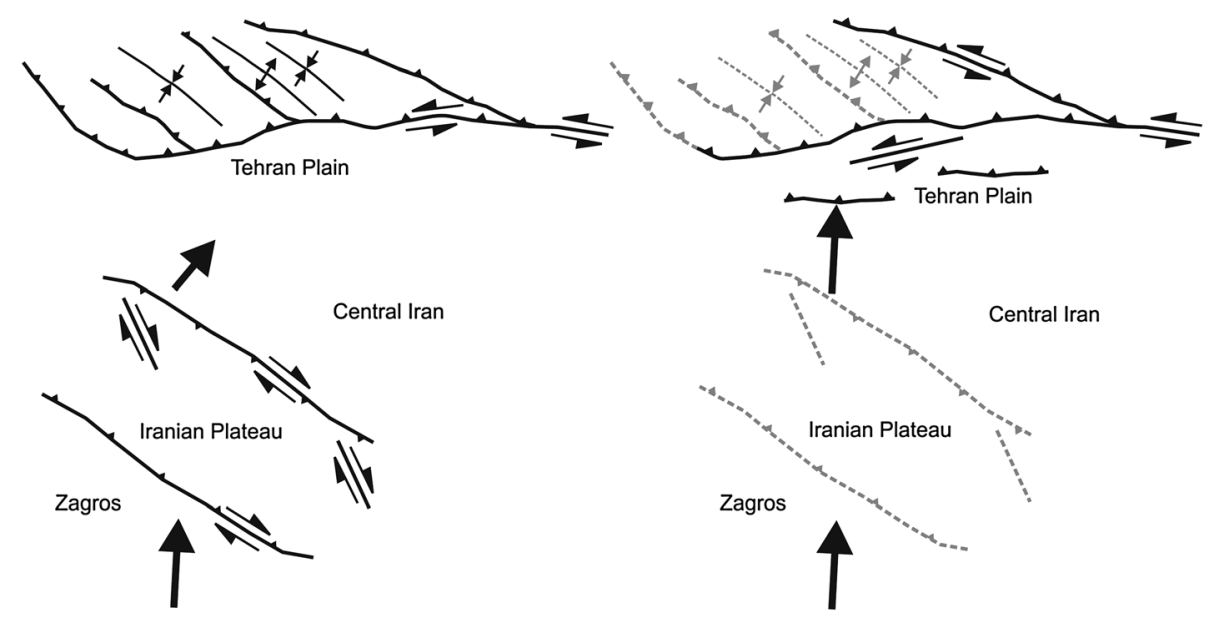

Figure 9. Sketch showing the evolution of the North Tehran Transpressional Duplex and the Tehran Plain from (a) 18-14 to $\sim 7-6 \mathrm{Ma}$ and (b) $\sim 7-6$ to $2 \mathrm{Ma}$. Black solid lines are active structures, and grey dashed lines are inactive structures. Black arrows represent the inferred regional shortening direction. The change in the kinematics of faulting at $\sim 7-6 \mathrm{Ma}$ is interpreted to reflect variations in orogenic processes across the collision zone, and in particular in the realm of the Iranian Plateau, which is inferred to have stopped or to have accommodated limited thrusting and strike-slip faulting during the last $\sim 7-6 \mathrm{Ma}$. The progressive decrease in right-lateral faulting is thought to have produced an anticlockwise rotation of the regional convergence vectors and a consequent reduction of obliquity between the regional shortening direction and the $\sim$ E-W-striking structures of the central Alborz mountains.

exhumation rate of $0.34-0.56 \mathrm{~mm} / \mathrm{yr}$ (Table 3 ). These firstorder calculations do not take into account heat advection, and thus represent maximum values.

[35] For the NTTw and PVT, we consider the top of the fossil ZPRZ $\left(\sim 130^{\circ} \mathrm{C}\right)$ as a reference horizon. Along the geologic cross section of Figure 8, this horizon is exposed in the hanging wall of the NTTw at an elevation of $2 \mathrm{~km}$. Accordingly, the paleo-depth of the top of the ZPRZ was at 5 to $3.6 \mathrm{~km}$ and rock uplift was 7 to $5.6 \mathrm{~km}$, corresponding to rock uplift rates of 0.33 to $0.47 \mathrm{~mm} / \mathrm{yr}$. Surface uplift for the area comprising the present-day location of the top of the ZPRZ is between 2 and $1.7 \mathrm{~km}$. This results in 5.3 to $3.6 \mathrm{~km}$ of exhumation during the last $18-14 \mathrm{Ma}$, corresponding to a long-term exhumation rate of 0.21 to $0.35 \mathrm{~mm} / \mathrm{yr}$ (Table 3 ). For the PVT thrust sheet, these values represent maximum estimates because the top of the ZPRZ is not well constrained by our samples. Given the complex kinematic history, these values are not solely related to SW-directed thrusting, but must also result from S-directed thrusting along the NTT since $\sim 7-6 \mathrm{Ma}$. This may include $2.8-3.7 \mathrm{~km}$ of rock uplift (long-term rate averaged over 7-6 m.y. of $0.46-0.61 \mathrm{~mm} / \mathrm{yr}$ ), $0.4-1.0 \mathrm{~km}$ of surface uplift, and $1.8-3.3 \mathrm{~km}$ of exhumation (long-term rate of $0.30-0.54 \mathrm{~mm} / \mathrm{yr}$ ) along the central segments of the NTT (Table 3 ).

[36] Based on local stratigraphic relationships (Figure 8), the top of the fossil ZPRZ in the NTTw and PVT hanging walls should be at least at $\sim 2$ to $2.5 \mathrm{~km}$ below the top of the Karaj Formation. Because exhumation is estimated to be 5.3 to $3.6 \mathrm{~km}$, we infer a thickness of the eroded Oligocene to Early Miocene foreland-basin sediments deposited onto the NTTw and PVT hanging walls between 3.3 and $1.1 \mathrm{~km}$. Similarly, for the EDT hanging wall, exhumation of 8.4 to $6.2 \mathrm{~km}$ and a depth of the base of ZPRZ of $\sim 5 \mathrm{~km}$ corresponds to a thickness of eroded foreland-basin deposits of $\sim 1.2$ to $3.4 \mathrm{~km}$. This is consistent with the minimum thickness $(\sim 0.7 \mathrm{~km})$ of Oligo-Miocene red beds still preserved on the EDT [Ballato et al., 2011]. In the case of structural burial of the footwall stratigraphic sequence from stacking of thrust sheets, the thickness of the eroded Oligo-Miocene forelandbasin deposits would be lower than our estimates.

Table 3. Rates of uplift and exhumation for the North Tehran Transpressional Duplex

\begin{tabular}{|c|c|c|c|c|c|}
\hline & Magnitude max $[\mathrm{km}]$ & Magnitude $\min [\mathrm{km}]$ & Rates $\max [\mathrm{mm} / \mathrm{yr}]$ & Rates $\min [\mathrm{mm} / \mathrm{yr}]$ & Reference horizon \\
\hline ROCK UPLIFT & 11,1 & 9,2 & 0,74 & 0,51 & Base of ZPRZ on EDT hanging \\
\hline SURFACE UPLIFT & 3,0 & 2,7 & 0,20 & 0,15 & wall since $17-15 \mathrm{Ma}$ \\
\hline EXHUMATION & 8,4 & 6,2 & 0,56 & 0,34 & \\
\hline ROCK UPLIFT & 7,0 & 5,6 & 0,47 & 0,33 & Top of ZPRZ on PVT and NTTw \\
\hline SURFACE UPLIFT & 2,0 & 1,7 & 0,13 & 0,10 & hanging wall since $17-15 \mathrm{Ma}$ \\
\hline EXHUMATION & 5,3 & 3,6 & 0,35 & 0,21 & \\
\hline ROCK UPLIFT & 3,7 & 2,8 & 0,61 & 0,46 & Base of NTT hangingwall since \\
\hline SURFACE UPLIFT & 1,0 & 0,4 & 0,17 & 0,08 & $7-6 \mathrm{Ma}$ \\
\hline EXHUMATION & 3,3 & 1,8 & 0,54 & 0,30 & \\
\hline
\end{tabular}




\subsection{Implications for Accommodation of Oblique Shortening in the SW Alborz Mountains}

[37] The transpressional duplex is located along the SW margin of the Alborz orocline, where the orientation of the orogen changes from E-W to NW-SE, possibly in response to indentation of the rigid South Caspian Basin block [Allen et al., 2003] (Figure 1). Interestingly, the central western Alborz range is characterized by several E-W-striking faults and associated folds, even where the orogen is clearly NW-oriented (e.g., the TF and the MFw; Figure 2). Most of these structures may be associated with inherited anisotropies causing a complex pattern of reactivation [Zanchi et al., 2006; Yassaghi and Madanipour, 2008; Yassaghi and Naeimi, 2011]. Similarly, the NW-striking EDT may correspond to an Eocene normal fault, as suggested by the abrupt change in sedimentary facies across this structure (Figure 6). The pre-strained crust seems to have dictated the structural style of deformation along the southwestern part of the orocline as well as the orogenic evolution of the southern deformation fronts of the Alborz mountains. Instead of accommodating NE-directed shortening along the southwestern bend with curved structures (i.e. north-dipping thrust faults NW-SE to E-W striking) as observed along the southeastern part of the orocline [e.g., Shabanian et al., 2012], older E-W-striking structures like the MFe, the TF, and possibly the NTT were reactivated (Figure 2). Given that the MFe-NTT system and the TF have a right-stepping geometry, new NW-striking frontal ramps (but also inherited structures such as the MFc and possibly the EDT) developed and accommodated oblique shortening (Figure 2). The evolution of these frontal ramps led to the efficient partitioning of oblique strain and inhibited the southward propagation of the deformation front in the Tehran plain (Figure 8).

[38] The inferred change in structural style at $\sim 7-6 \mathrm{Ma}$ would have involved a decrease in the obliquity of the shortening direction with respect to the pre-existing structures, from NE to N-NNE. Recently, Allen et al. [2011] documented at least $250 \mathrm{~km}$ of right-lateral motion on NW- to NNW-striking strike-slip faults in central and NW Iran (Iranian Plateau, see next section) before $5 \mathrm{Ma}$. This should have promoted an along-strike widening of the collision zone and hence NEdirected convergence between central Iran and the Alborz mountains (Figure 9), a scenario which is corroborated by recent paleomagnetic data [Mattei et al., 2012]. Because the approximately $\mathrm{N}-\mathrm{S}$-oriented plate convergence direction did not change during the last $20 \mathrm{Ma}$ [e.g., McQuarrie et al., 2003] the progressive decrease in right-lateral shearing across the collision zone should have produced an anticlockwise rotation of the convergence vector to the present-day, N-S oriented shortening direction (Figures 1a). Hence, a decrease in the obliquity of shortening by up to $30^{\circ}$ is suggested to have occurred (Figure 9). This kinematic change could be responsible for the reactivation of the NTT as a frontal ramp and may have possibly triggered the onset of deformation in the Tehran plain.

[39] It should be noted that the crustal block underlying the South Caspian Basin started moving northwestward accompanied by clockwise rotation sometime between 10 and $2 \mathrm{Ma}$, possibly in response to subduction processes [Jackson et al., 2002; Ritz et al., 2006; Hollingsworth et al., 2008; Djamour et al., 2010]. This process has produced orogen-scale, leftlateral shearing, which is thought to have caused local oblique extension, as documented along the major lateral and oblique ramps of the transpressional duplex, including the MFe, the $\mathrm{TF}$, and the eastern termination of the NTT [Ritz et al., 2006, Landgraf et al., 2009; Nazari et al., 2009]. Extensional structures, however, seem to be of Quaternary age, and hence the S-directed phase of thrusting at $\sim 7-6 \mathrm{Ma}$ must pre-date the clockwise rotation and the subduction of the South Caspian Basin.

\subsection{Implications for Collision Processes between Arabia and Eurasia}

[40] Our data have major implications for lithospheric evolution and deformation processes across the Arabia-Eurasia collision zone. Regarding the early stages of continental collision, the onset of enhanced exhumation at 18-14 Ma confirms recent findings that an acceleration in tectonic (i.e., shortening and exhumation rates) and sedimentary (i.e., subsidence rates) processes across the Alborz mountains and the entire collision zone began after $20 \mathrm{Ma}$ [Ballato et al., 2008, 2011], or possibly earlier ( $25 \mathrm{Ma}$, [Mouthereau et al., 2012]), about 10-15 m.y. after an inferred Late Eocene-Early Oligocene collision, [e.g., Ballato et al., 2011; Agard et al., 2011; Van Hunan and Allen, 2011; Mouthereau et al., 2012].

[41] In this study, we refer to the Iranian Plateau as the elevated (mean elevation $1.5-2 \mathrm{~km}$ ), low relief, and mostly internally drained morphotectonic province comprising the Sanandaj-Sirjan Zone (SSZ), the Urumieh-Dokhtar Volcanic Zone (UDVZ), and the basin area in between (Figure 1). Geophysical data from the plateau reveal an isostatically compensated 45- to 65-km-thick crust [Paul et al., 2010; Motavalli-Anbaran et al., 2011; Jiménez-Munt et al., 2012]. Central Iran, which has a lower elevation $(0.5-1 \mathrm{~km})$, is less deformed, and has a 35- to 40-km-thick crust [Paul et al., 2010; Motavalli-Anbaran et al., 2011; Jiménez-Munt et al., 2012] is excluded from the plateau. The presence of a thickened crust on the southern European margin implies that slowly deforming to presently inactive areas of the Iranian Plateau (Figure 1), must have experienced up to $10-30 \mathrm{~km}$ of crustal thickening and shortening in the past. These are minimum values if we consider that after the Eocene extensional tectonism, which was locally associated with the development of metamorphic core complexes [Verdel et al., 2007; Karagaranbafghi et al., 2012], the crust of the Eurasian margin must have been thinner than a normal, unstretched, continental crust. Consequently, these areas must have accommodated a significant fraction of the $500-800 \mathrm{~km}$ of post-collisional plate convergence [Hatzfeld and Molnar, 2010] accompanied by right-lateral shearing [Allen et al., 2011] (Figure 9).

[42] To date, geologic data reflecting plateau uplift have largely remained unclear and difficult to interpret due to the lack of suitable geologic archives, unequivocal geologic signals in sedimentary deposits within and along the plateau flanks, and limited information on the thermal history of associated exhumed rocks. It has been suggested that the attainment of high topography of the Iranian Plateau has occurred slowly since the Early Miocene by lithospheric shortening and thickening processes in association with an along-strike expansion of the collision zone. This process was sustained until $\sim 5 \mathrm{Ma}$, when a plate-tectonic reorganization occurred and the orogenic fronts may have migrated to less elevated regions [Allen et al., 2004, 2011]. Similarly, it has been suggested that uplift of the Iranian Plateau has 
occurred steadily through shortening and thickening since at least $10 \mathrm{Ma}$ [Morley et al., 2009; Mouthereau, 2011]. Alternatively, lithospheric delamination following lithospheric thickening might have occurred at about $12-10 \mathrm{Ma}$, causing rapid plateau uplift, accelerated exhumation of the northern areas of the collision zone, and termination of contractional deformation within the plateau [Hatzfeld and Molnar, 2010]. Slab break-off is predicted to have similar effects on the upper crust, and is commonly invoked to explain the uplift of the Eastern Anatolian Plateau [e.g., Şengör et al., 2003; Keskin, 2003]. The expected lateral propagation rate of a tear in the Tethyan slab of 100 to $150 \mathrm{~mm} / \mathrm{yr}$ [van Hunan and Allen, 2011] could explain delayed onset of break-off related uplift in southern Central Anatolia (starting at $\sim 7$ to $5.5 \mathrm{Ma}$ [Cosentino et al., 2012; Schildgen et al., 2012]) compared to Eastern Anatolia (starting at 13 to $11 \mathrm{Ma}$ [e.g., Gelati, 1975; Pearce et al., 1990]), and could also potentially explain delayed effects on the Iranian plateau if the tear also propagated eastward. If our assessment of the causal relationship between uplift of the Iranian Plateau and change in the obliquity of shortening along the Alborz mountains is correct, then shortening across the plateau should have occurred until 7-6 Ma. It is not clear, however, if this was coeval with the plate-tectonic reorganization at $\sim 5 \mathrm{Ma}$ [Allen et al., 2004].

[43] Finally, our data have implications for the relative motion of the South Caspian Basin within the collision zone. The present-day shortening direction in the Alborz mountains ( $\sim \mathrm{N} 20^{\circ}$ E; [Masson et al., 2007]) results from the combination of northward motion of the Iranian Plateau/Central Iran and northwestward motion of the South Caspian Basin [e.g., Jackson et al., 2002] (Figure 1). Without the northwestward motion of the South Caspian Basin, the left-lateral shearing component across the central Alborz mountains would be very reduced or absent, and the shortening direction would be about N-S as observed regionally at the longitude of Tehran (Figure 1a). The S-directed thrusting at $\sim 7-6 \mathrm{Ma}$ implies that either the Caspian Basin was stable with respect to Eurasia, or that it was moving to the S [Allen et al., 2003] or to the north [Ritz, 2009]. In any case, the S-directed phase of thrusting should predate the westward motion of the Caspian Basin. This process could be as young as $\sim 2 \mathrm{Ma}$, as suggested by Ritz et al. [2006], or it may have been associated with the plate-tectonic reorganization at $\sim 5 \mathrm{Ma}$, as suggested by Allen et al. [2004]. In either case, this would also imply that the westward motion of the South Caspian Basin might not be as old as $\sim 10 \mathrm{Ma}$, as suggested by Hollingsworth et al. [2008].

\section{Conclusions}

[44] Accelerated cooling of the upper crust in southern Alborz mountains, associated with the growth of the North Tehran Transpressional Duplex, started at about 18-14 Ma during NE-oriented shortening. The duplex developed along the southwest margin of the Alborz orocline during the nucleation (and possibly reactivation) of NW-striking frontal ramps connecting right-stepping, E-W striking inherited structures, which were reactivated as lateral and oblique ramps. SW-directed thrusting across the frontal ramps of the duplex led to tectonic repetition of the fossil ZPRZ. AHe data record an $\sim 18-14 \mathrm{Ma}$ pulse of exhumation, and most likely an additional phase between $\sim 9.5-7.5 \mathrm{Ma}$ during similar kinematic conditions. Uniform cooling ages of $\sim 7-6 \mathrm{Ma}$ along the southern margin of the duplex (NTT) and across the major frontal ramps, however, suggest a third event of exhumation associated with S-directed thrusting, linked to the reactivation of the NTT as a single master thrust fault. This change was most likely caused by an anticlockwise rotation of the shortening direction from NE- to N-NNE. Thrusting along the EDT produced 8.4 to $6.2 \mathrm{~km}$ of exhumation, during the last $\sim 18-14 \mathrm{Ma}$, with the exposure of fully reset samples. Thrusting along the NTTw and PVT accounts for 5.3 to $3.6 \mathrm{~km}$ of exhumation and led to the exposure of partially reset samples.

[45] The 18-14 Ma pulse of deformation is consistent with other data from the Alborz range and adjacent regions showing widespread upper and lower-plate deformation starting from $\sim 20 \mathrm{Ma}$ or earlier. Regarding the more recent evolution of the collision zone, we interpret the change in structural style across the transpressional duplex at $\sim 7-6 \mathrm{Ma}$ to reflect the termination of strike-slip faulting and possibly thrusting across the Iranian Plateau. This suggests that by $\sim 7-6 \mathrm{Ma}$, the Iranian Plateau had probably reached elevations similar to the present-day through lithospheric shortening and thickening, mantle delamination, or a combination thereof. It is not clear, however, if this event coincided or triggered the plate-tectonic reorganization within the collision zone at $\sim 5 \mathrm{Ma}$. Finally, the $\sim 7-6 \mathrm{Ma}$ pulse in deformation should predate the westward motion of the South Caspian Basin.

[46] Acknowledgment. This research was funded by the German Science Foundation (DFG) with the Leibniz Award to M.R.S. (STR 373/16-1) and grant (STR 373/19-1) to M.R.S. and A.F., the graduate-school program of Potsdam University (GRK1364), the U.S. National Science Foundation (EAR9902932 to Gary Axen), and the University of Tehran Research Council (651/ $1 / 328$ to J.H.). We are indebted to the Tehran Building and Housing Research Center and the Geological Survey of Iran for logistical support. T. Roeper is thanked for help with sample preparation. We are grateful to B. Ghorbal, R. Kislitsyn, S. Brichau and students of the (U-Th)/He laboratory at the University of Kansas for providing technical support. E. Kirby, E. Macaulay, R. Sobel, R. Thiede and J. Zamagni are thanked for discussions and suggestions. T. Schildgen is thanked for her help with the text and constructive comments. We also acknowledge Tectonics editor O. Oncken, the associate editor, J. Spotila, and an anonymous reviewer for their constructive reviews. P.B. thanks A. Moeller, B. Mocek and the Stockli family for their hospitality while staying at the University of Kansas. This work is dedicated to the late B. Mocek.

\section{References}

Abbassi, M.R., and Y. Farbod (2009), Faulting and Folding in Quaternary Deposits of Tehran's Piedmont (Iran), J. Asian Earth Sci, 34, 522-531.

Agard, P., J. Omrani, L. Jolivet, H. Whitechurch, B. Vrielynck, W. Spakman, P. Monié, B. Meyer, and R. Wortel (2011), Zagros orogeny: a subductiondominated process, Geol Mag, doi:10.1017/S001675681100046X.

Aghanabati, A., and A.R. Hamedi (1994), Geological map of Semnan quadrangle: Geological Survey of Iran, scale 1:250,000, 1 sheet.

Alipoor, R., M., Zaré, and M. R., Ghassemi (2012), Inception of activity and slip rate on the Main Recent Fault of Zagros Mountains, Geomorphology, 175-176, 86-97.

Allen, M., M. R. Ghassemi, M. Shahrabi, and M. Qorashi (2003), Accommodation of late Cenozoic oblique shortening in the Alborz range, northern Iran, J. Struct. Geol., 25, 659-672.

Allen, M., J. Jackson, and R. Walker (2004), Late Cenozoic reorganization of the Arabia-Eurasia collision and the comparison of short-term and long term deformation rates, Tectonics, 23, TC2008, doi:10.1029/2003TC001530.

Allen, M.B., M. Kheirkhah, M.H. Emami, and S.J. Jones (2011), Right-lateral shear across Iran and kinematic change in the Arabia-Eurasia collision zone, Geophys J Int, 184, 555-574, doi:10.1111/j.1365-246X.2010.04874.x.

Amidi, S.M. (1984), Geological map of Saveh quadrangle: Geological Survey of Iran, scale 1:250,000, 1 sheet.

Amini, B., M.H., Emami, K. Jamshidi and A.M. Afsharian Zadeh (1993), Geological map of Tehran quadrangle: Geological Survey of Iran, scale 1:100,000, 1 sheet.

Amini, B, H. Rashid, M. Rezaian, S. Allahmadadi, M. R. Zabihi, B. Vahdati Daneshmand, and M. Haddadan (2004), Geological map of Iran, Garmsar sheet, scale 1:100,000, Geol. Surv. of Iran, Tehran. 


\section{BALLATO ET AL.: COLLISIONAL OBLIQUE STRAIN}

Axen, G. J., P. J. Lam, M. Grove, D. F. Stockli, and J. Hassanzadeh (2001), Exhumation of the west-central Alborz mountains, Iran, Caspian subsidence, and collision-related tectonics, Geology, 29, 559-562.

Ballato, P., N.R. Nowaczyk, A. Landgraf, M.R. Strecker, A. Friedrich, and S.H. Tabatabaei (2008), Tectonic control on sedimentary facies pattern and sediment accumulation rates in the Miocene foreland basin of the southern Alborz mountains, northern Iran, Tectonics, 27(TC6001), 1-20.

Ballato, P., C.E. Uba, A. Landgraf, M.R. Strecker, M. Sudo, D.F. Stockli, A. Friedrich, and S.H. Tabatabaei (2011), Arabia-Eurasia continental collision: insights from late Tertiary foreland-basin evolution in the Alborz mountains, northern Iran, Geol Soc. Am Bull, 123, 106-131.

Ballato, P., A. Mulch, A. Landgraf, M. R. Strecker, M. C. Dalconi, A. Friedrich, and S. H. Tabatabaei (2010), Middle to Late Miocene Middle Eastern climate from stable oxygen and carbon isotope data, southern Alborz mountains, N Iran, Earth Planet Sci Lett, 300, 125-138.

Berberian, M., and G. C. P. King (1981), Towards a paleogeography and tectonic evolution of Iran, Can. J. Earth Sci., 18(2), 210-265.

Brunet, M. F., M. V. Korotaev, A. V. Ershov, and A. M. Nikishin (2003), The South Caspian Basin: A review of its evolution from subsidence modeling, Sediment. Geol., 156, 119-148.

Chapman, D. S. (1986), Thermal gradients in the continental crust, in the nature of the Lower Continental Crust, edited by J. B. Dawson, D. A Carswell, J. Hall, and K. iI. Wedepohl, Geol. Soc. Spec. Publ., London, vol. 24 , pp. $63-70$

Cosentino, D., T.F. Schildgen, P. Cipollari, C. Faranda, E. Gliozzi, N Hudáčková, S. Lucifora, and M.R. Strecker (2012), Late Miocene surface uplift of the southern margin of the Central Anatolian plateau, Central Taurides, Turkey, Geol. Soc. Am. Bull., 124, 133-145.

Cunningham, D. (2005), Active intracontinental transpressional mountain building in the Mongolian Altai: Defining a new class of orogen, Earth Planet Sci Lett, 240, 436-444.

Dewey, J.F., R.E. Holdsworth, and R.A. Strachan (1998), Transpression and transtension zones: continental transpressional and transtensional tectonics. Geol. Soc. Spec. Publ. London, 135, 1-14.

Djamour, Y., et al. (2010), GPS and gravity constraints on continental deformation in the Alborz mountain range, Iran, Geophys. J. Int., 183 , 1287-1301, doi:10.1111/j.1365-246X.2010.04811.x.

Ehlers, T.A. (2005), Crustal thermal processes and thermochronometer interpretation. Rev Mineral Geochem, 58, 315-350.

Engdahl, E., J. Jackson, S. Myers, E. Bergman, and K. Priestley (2006), Relocation and assessment of seismicity in the Iran region, Geophys. J. Int., 167, 761-788.

Farley, K.A., R.W. Wolf, and L.T. Silver (1996), The effects of long alphastopping distances on (U-Th)/He ages, Geochim Cosmochim Acta, 60, 4223-4229.

Farley, K. (2000), Helium diffusion from apatite; general behavior as illustrated by Durango fluorapatite. J Geophys Res, 105(B2), 2903-2914.

Farley, K.A., and D. F. Stockli (2002), (U-Th)/He dating of phosphates: Apatite, Monazite, and Xenotime, in Geochemical, Geobiological, and Materials importance edited by Kohn, M.J., et al., Phosphates: Washington DC, Geochemical Society and Mineralogical Society of America, Rev mineral geochem, 48, 559-577.

Fitzgerald, P.G., R. B. Sorkhabi, T. F. Redfield, and E. Stump (1995), Uplift and denudation of the central Alaska Range: a case study in the use of apatite fission-track thermochronology to determine absolute uplift parameters, J Geophys Res, 100, 20175-20191.

Gelati, R. (1975), Miocene marine sequence from Lake Van, Eastern Turkey. Riv. Ital. Paleontol. Stratigr., 81, 477-490.

Ghassemi, M.R. (2005), Drainage evolution in response to fold growth in the hanging-wall of the Khazar fault, north-eastern Alborz, Iran, Basin Research, 17(3), 425-436.

Guest, B., G. J. Axen, P. S. Lam, and J. Hassanzadeh (2006a), Late Cenozoic shortening in the westcentral Alborz mountains, northern Iran, by combined conjugate strike-slip and thin-skinned deformation, Geosphere, 2, 35-52, doi:10.1130/GES00019.1.

Guest, B., D. F. Stockli, M. Grove, G. J. Axen, P. S. Lam, and J. Hassanzadeh (2006b), Thermal histories from the central Alborz mountains, northern Iran: Implications for the spatial and temporal distribution of deformation in northern Iran, Geol. Soc. Am. Bull., 118, 1507-1521, doi: 10.1130/ B25819.1.

Guest, B., A. Guest, and G. Axen, (2007), Late Tertiary tectonic evolution of northern Iran: A case for simple crustal folding, Global Planet Change, 58, 435-453, doi:10.1016/j.gloplacha.2007.02.014

Haghipour, A., H. Taraz, and F. Vahdati Daneshmand (1987), Geological quadrangle map of Iran, Tehran sheet, scale 1:250,000, Geol. Surv. of Iran, Tehran.

Hain, M. P., M. R. Strecker, B. Bookhagen, R. N. Alonso, H. Pingel, and A. K. Schmitt (2011), Neogene to Quaternary broken foreland formation and sedimentation dynamics in the Andes of NW Argentina $\left(25^{\circ} \mathrm{S}\right)$, Tectonics, 30, TC2006, doi:10.1029/2010TC002703

Hatzfeld, D., and P. Molnar (2010), Comparisons of the kinematics and deep structures of the Zagros and Himalaya and of the Iranian and Tibetan plateaus and geodynamic implications, Rev. Geophys., 48, RG2005, doi:10.1029/2009RG000304.

Holdsworth, R.E., C. A. Butler, and A.M. Roberts (1997), The recognition of reactivation during continental deformation, J Geol Soc London, 154, 73-78.

Hollingsworth, J., J. Jackson, R. Walker, and H. Nazari (2008), Extrusion tectonics and subduction in the eastern South Caspian region since 10 Ma, Geology, 36(10), 763-766.

Horton, B. K., J. Hassanzadeh, D. F. Stockli, G. J. Axen, R. J. Gillis, B. Guest, A. Amini, M. D. Fakhari, S. M. Zamanzadeh and M. Grove (2008), Detritial zircon provenance of Neoproterozoic to Cenozoic deposits in Iran: implications for chronostratigraphy and collision tectonics, Tectonophysics, 451, 97-122, doi: 10.1016/j.tecto.2007.11.063.

House, M. A., K. A. Farley, and B. P. Kohn (1999), An empirical test of helium diffusion in apatite: borehole data from the Otway basin, Australia, Earth Planet Sci Lett, 170, 463-474.

Jackson, J., K. Priestly, M. B. Allen, and M. Berberian (2002), Active tectonics of the South Caspian Basin, Geophys J Int, 190, 1311-1324.

Jiang, D., S. Lin, P. F. Williams (2001), Deformation path in high-strain zones, with reference to slip partitioning in transpressional plate boundary regions, J Struct Geol, 23, 991-1005.

Jiménez-Munt, I., M. Fernàndez, E. Saura, J. Vergés, D. Garcia-Castellanos (2012), 3-D lithospheric structure and regional/residual Bouguer anomalies in the Arabia-Eurasia collision (Iran), Geophys J Int, 177, 676-690.

Jones, R. R., and G. P. W. Tanner (1995), Strain partitioning in transpression zones, J Struct Geol, 17, 793-802.

Karagaranbafghi, F., Foeken, J. P. T., Guest, B., Stuart, F. M. (2012), Cooling history of the Chapedony metamorphic core complex, Central Iran: Implications for the Eurasia-Arabia collision, Tectonophysics, 524-525, 100-107.

Keskin, M. (2003), Magma generation by slab steepening and breakoff beneath a subduction accretion complex: an alternative model for collision-related volcanism in Eastern Anatolia, Turkey, Geophys. Res. Lett., 30(24), 8046, doi:10.1029/2003GL018019.

Khadivi, S., F. Mouthereau, J. Barbarand, T. Adatte, and O. Lacombe (2012), Constraints on palaeodrainage evolution induced by uplift and exhumation on the southern flank of the Zagros-Iranian Plateau, J Geol Soc London, 169(1), 83-97.

Kirby, E., P. W. Reiners, M. A. Krol, K. X. Whipple, K. V. Hodges, K. A Farley, W. Tang, and Z. Chen (2002), Late Cenozoic evolution of the eastern margin of the Tibetan Plateau: Inferences from 40Ar/39Ar and (U-Th)/He thermochronology, Tectonics, 21(1), 1001, doi:10.1029/ 2000 TC001246.

Landgraf, A., P. Ballato, M. R. Strecker, A. Friedrich, S. H. Tabatabaei, and M. Shahpasandzadeh (2009), Fault-kinematic and geomorphic observations along the North Tehran Thrust and Mosha Fasham Fault, Alborz mountains, Iran: implications for fault-system evolution and interaction in a changing tectonic regime, Geophys J Int, 177, 676-690.

Lock, J., and S. Willett (2008), Low-temperature thermochronometric ages in fold-and-thrust belts, Tectonophysics, 456, 147-162.

Masson, F., M. Anvari, Y. Djamour, A. Walpersdorf, F. Tavakoli, M. Daignières, H. Nankali and S. van Gorp (2007), Large-scale velocity field and strain tensor in Iran inferred from GPS measurements: new insight for the Present-day deformation pattern within NE Iran, Geophys. Journal Int., 170, 436-440, doi:10.1111/j.1365-246X.2007.03477.x.

Mattei, M., F. Cifelli, G. Muttoni, A. Zanchi, F. Berra, F. Mossavvari, and S.A. Eshraghi (2012), Neogene block rotation in central Iran: Evidence from paleomagnetic data, Geol Soc. Am Bull, 124, 943-956.

McQuarrie, N., J. M. Stock, C. Verdel, and B. P. Wernicke (2003), Cenozoic evolution of Neotethys and implications for the causes of plate motions, Geophys. Res. Lett., 30, 2036, doi:10.1029/2003GL017992.

Miller, D. D. (1998), Distributed shear, rotation, and partitioned strain along the San Andreas fault, central California, Geology, 26, 867-870.

Miller, K.G., M. A. Kominz, J. V. Browning, J. D. Wright, G. S. Mountain, M. E. Katz, P. J. Sugarman, B. S. Cramer, N. Christie-Blick, and S. F. Pekar (2005), The Phanerozoic record of global sea-level change, Science, 310, 1293-1298.

Mohajjel, M., C. L. Fergusson, and M. R. Sahandi (2003), CretaceousTertiary convergence and continental collision, Sanandaj-Sirjan Zone, western Iran, J. Asian Earth Sci., 21, 397-412.

Molnar, P., and P. England (1990), Late Cenozoic uplift of mountain ranges and global climate change: Chicken or egg?, Nature, 346, 29-34.

Moore, M.A., and P.C. England (2001), On the inference of denudation rates from cooling ages of mineral, Earth Planet Sci Lett, 185, 265-284.

Mora, A., M. Parra, M.R. Strecker, A. Kammer, C. Dimaté, and F. Rodríguez (2006), Cenozoic contractional reactivation of Mesozoic extensional structures in the Eastern Cordillera of Colombia, Tectonics, 25, TC2010, doi: 10.1029/2005TC001854.

Morley, C., B. Kongwung, A.A. Julapour, M. Abdolghafourian, M. Hajian, D. Waples, J. Warren, H. Otterdoom, K. Srisuriyon, and H. Kazemi (2009), Structural development of the major Late Cenozoic basin and 


\section{BALLATO ET AL.: COLLISIONAL OBLIQUE STRAIN}

transpressional belt in Central Iran: the Central Basin in the Qom-Saveh area, Geosphere, 5, 325-362.

Motavalli-Anbaran, S.-H., H. Zeyen, M.-F. Brunet, and V. E. Ardestani (2011), Crustal and lithospheric structure of the Alborz Mountains, Iran, and surrounding areas from integrated geophysical modeling, Tectonics, 30, TC5012, doi:10.1029/2011TC002934.

Mouthereau, F., O. Lacombe, and J. Vergés (2012), Building the Zagros collisional orogen: timing, strain distribution and the dynamics of Arabia Eurasia plate convergence. Tectonophysics, 532-535, 27-60, doi: 10.1016/ j.tecto.2012.01.022.

Mouthereau, F. (2011), Timing of uplift in the Zagros belt/Iranian plateau and accommodation of late Cenozoic Arabia-Eurasia convergence, Geol Mag, 148(5-6), 726-738, doi:10.1017/s0016756811000306.

Nazari, H., J.-F. Ritz, R. Salamati, A. Shafei, A. Ghassemi, J.-L. Michelot, M. Massault, and M. Ghorashi (2009), Morphological and Paleoseismological Analysis along the Taleghan Fault (Central Alborz, Iran), GJI, 178(2), 1028-1041, doi: 10.1111/j.1365246X.2009.04173.x.

Oldow, J.S., A.W. Bally, and H.G. Avé Lallemant (1990), Transpression, orogenic float, and lithospheric balance, Geology, 18, 991-994, doi: 10.1130/0091-7613(1990)0182.3.CO;2.

Paul, A., D. Hatzfeld, A. Kaviani, M. Tatar, and C. Péquegnat (2010), Seismic imaging of the lithospheric structure of the Zagros mountain belt (Iran), in Tectonic and Stratigraphic Evolution of Zagros and Makran During the Mesozoic-Cenozoic, edited by P. Leturmy and C. Robin, Geol. Soc. Spec. Publ., London, vol. 330, pp. 5-18.

Pearce, J. A., J.F. Bender, S.E. De Long, W.S.F. Kidd, P.J. Low, Y. Güner, F. Şaroğlu, Y. Yılmaz, S. Moorbath, and J.G. Mitchell (1990), Genesis of collision volcanism in Eastern Anatolia, Turkey, J. Volcan. Geotherm. Res., 44, 189-229.

Reiners P.W., and K.A. Farley (2001), Influence of crystal size on apatite (U-Th)/He thermochronology: an example from the Bighorn mountains, Wyoming, Earth Planet Sci Lett, 188, 413-420.

Reiners, P.W., and M.T. Brandon, 2006. Using thermochronology to understand orogenic erosion. Annual Review of Earth and Planetary Sciences, 34, 419-466.

Reiners, P.W., K.A. Farley, H.J. Hickes (2002), He diffusion and (U-Th)/He thermochronometry of zircon: Initial results from Fish Canyon Tuff and Gold Butte, Tectonophys, 349, 247-308,

Reuter, M., W.E. Piller, M. Harzhauser, O. Mandic, B. Berning, F. Rögl, A. Kroh, M.P. Aubry, U. Wielandt-Schuster, and A. Hamedani (2009), The Oligo-Miocene Qom Formation (Iran): Evidence for an early Burdigalian restriction of the Tethyan seaway and closure of its Iranian gateways, Int $J$ Earth Sci, 98, 627-650, doi: 10.1007/s00531-007-0269-9.

Rezaeian, M., A. Carter, N. Hovius, and M. B. Allen (2012), Cenozoic exhumation history of the Alborz Mountains, Iran: New constraints from lowtemperature chronometry, Tectonics, 31, TC2004, doi:10.1029/2011TC002974.

Rieben, H. (1955), The geology of the Tehran plain, Am. J. Sci., 253, 617-639.

Ritz, J.-F., H. Nazari, A. Ghassemi, R. Salamati, A. Shafei, S. Solaymani, and P. Vernant (2006), Active transtension inside central Alborz: A new insight into northern Iran - southern Caspian geodynamics, Geology, 34, 477-480, doi: $10.1130 / \mathrm{G} 22319.1$.

Ritz, J.-F., 2009. Extrusion tectonics and subduction in the eastern South Caspian region since $10 \mathrm{Ma}$ : COMMENT, Geology, 37, e191.

Sanderson, D., and R. D. Marchini (1984), Transpression, J Struct Geol, 6, 449-458.

Schildgen, T.F., D. Cosentino, B. Bookhagen, S. Niedermann, C. Yıldırım, H. P. Echtler, and M.R. Strecker (2012), Multi-phased uplift of the southern margin of the Central Anatolian plateau, Turkey: A record of tectonic and upper mantle processes, Earth Planet Sci. Lett., 317-318, 85-95.

Şengör, A.M.C., S. Özeren, T. Genç, and E. Zor (2003), East Anatolian high plateau as a mantle-supported, north-south shortened domal structure, Geophys. Res. Lett., 30(24), 8045, doi:10.1029/2003GL017858.

Shabanian, E., V. Acocella, A. Gioncada, H. Ghasemi, and O. Bellier (2012), Structural control on volcanism in intraplate post collisional settings: Late Cenozoic to Quaternary examples of Iran and Eastern Turkey, Tectonics, 31, TC3013, doi:10.1029/2011TC003042.

Spotila, J.A., K. Farley, and K. E. Sieh (1998), Uplift and erosion of the San Bernardino Mountains associated with transpression along the San Andreas fault, California, as constrained by radiogenic helium thermochronometry, Tectonics, 17, 360-378.

Spotila JA, Farley KA, Yule JD, Reiners PW (2001) Near-field convergence along the San Andreas fault zone in southern California, based on exhumation constrained by (U-Th)/He dating. J Geophys Res 106:26731-26746.

Spotila, J. A., N. Niemi, R. Brady, M. House, J. Buscher, and M. Oskin (2007), Long-term continental deformation associated with transpressive plate motion: The San Andreas fault, Geology, 35(11), 967-970, doi:10.1130/G23816A.1.

Stockli, D. F., K.A. Farley, and T. Dumitru (2000), Calibration of the (U-Th)/ He thermochronometer on an exhumed fault block, White Mountains, California, Geology, 28, 983-986.
Stockli, D. F., B. E. Surpless, T. A. Dumitru, and K. A. Farley (2002), Thermochronological constraints on the timing and magnitude of Miocene and Pliocene extension in the central Wassuk Range, western Nevada, Tectonics, 21, 10-28, 10.1029/2001TC001295.

Stockli, D.F., T. A. Dumitru, M. O. McWilliams, and K. A. Farley (2003), Cenozoic Tectonic Evolution of the White Mountains, California and Nevada, Geol Soc Am Bull, 115, 788-816.

Stockli, D. F., K. A. Farley (2004), Empirical constraints on the titanite (UTh)/He partial retention zone from the KTB drill hole, Chem. Geol., 227, 223-36.

Stuwe, K., L. White, R. Brown (1994), The influence of eroding topography on steady-state isotherms-application to fission track analysis, Earth Planet Sci Lett, 124, 63-74.

Talebian, M., and J. Jackson (2004), A reappraisal of earthquake focal mechanisms and active shortening in the Zagros Mountains of Iran, Geophys. J. Int., 156, 506-526.

Tatar, M., J. Jackson, D. Hatzfeld, and E. Bergman (2007), The 28 May 2004 Baladeh Earthquake (Mw 6.2) in the Alborz, Iran: Overthrusting the South Caspian Basin margin, Partitioning of the Oblique Convergence, and Seismic Hazard of Tehran, Geophys. J. Int., 170, 249-261.

Teyssier, C., B. Tikoff, and M. Markley (1995), Oblique plate motion and continental tectonics, Geology, 23, 447-450.

Tikoff, B., and C. Teyssier (1994), Strain modeling of displacement-field partitioning in transpressional orogens, J Struct Geol, 16, 1575-1588.

Vahdati Daneshmand, F., and A. Saidi (1991), Geological map of Sari quadrangle: Geological Survey of Iran, scale 1:250,000, 1 sheet.

Vahdati Daneshmand, F., Z. Hosseini, A. Afsharinzadeh, and Z. Chaichi (1991), Geological quadrangle map of Iran, Amol sheet, scale 1:250,000, Geol. Surv. of Iran, Tehran.

Van Hunan, J., and M. B. Allen (2011), Continental collision and slab breakoff: a comparison of 3-D numerical models with observations, Earth Planet Sci. Lett., 302, 27-37.

Verdel, C., B. P. Wernicke, J. Ramezani, J. Hassanzadeh, P. R. Renne, and T. L. Spell (2007), Geology and thermochronology of Tertiary Cordilleranstyle metamorphic core complexes in the Saghand region of central Iran, Geol. Soc. Am. Bull., 119, 961-977, doi:10.1130/B26102.1.

Verdel, C. S., B. P. Wernicke, J. Hassanzadeh, and B. Guest (2011), A Paleogene extensional arc flare-up in Iran, Tectonics, 30, TC3008, doi: $10.1029 / 2010$ tc002809

Vernant, P., F. Nilforoushan, D. Hatzfeld, M. R. Abbassi, C. Vigny, F. Masson, H. Nankali, J. Martinid, A. Ashtiani, R. Bayer, F. Tavakoli, and J. Chery (2004), Present-day crustal deformation and plate kinematics in the Middle East constrained by GPS measurements in Iran and northern Oman, Geophys. J. Int., 157, 381-398, doi: 10.1111/ j.1365-246X.20004.02222.x.

Westaway, R. (1994), Present-day kinematics of the Middle East and eastern Mediterranean, J. Geophys. Res., 99, 12,071-12,090.

Wilcox, R. E., and T. P. Harding (1973), Basic Wrench Tectonics, AAPG Bulletin, 57, doi: 10.1306/819A424A-16C5-11D7-8645000102C1865D.

Wilmsen, M., F. T. Fürsich, K. Seyed-Emami, M. R. Majidifard, and J. Taheri (2009), The Cimmerian Orogeny, in northern Iran: tectono-stratigraphic evidence from the foreland, Terranova, 21, 211-218.

Wolf, R. A., K. A. Farley, and L. T. Silver (1996), Helium diffusion and lowtemperature thermochronometry of apatite, Geochim Cosmochim Ac, 60, 4231-4240.

Wolfe, M. R., and D. F. Stockli (2010), Zircon (U-Th)/He thermochronometry in the KTB drill hole, Germany, and its implications for bulk He diffusion in Zircon, Earth Planet Sc Lett, 295, 69-82.

Woodcock N. H., and M. Fischer (1986), Strike-slip duplexes, J Struct Geol, 8, 725-735.

Yassaghi, A., and S. Madanipour (2008), Influence of a transverse basement fault on along-strike variations in the geometry of an inverted normal fault: case study of the Mosha Fault, Central Alborz Range, Iran, J Struct Geol, 30, 1507-1519.

Yassaghi, A., and A. Naeimi (2011), Structural analysis of the Gachsar subzone in central Alborz range; constrain for inversion tectonics followed by the range transverse faulting, Int J Earth Sci, 100(6), 1237-1249, doi: 10.1007/s00531-010-0537-y.

Zachos, J., M. Pagani, L. Sloan, E. Thomas, and K. Billups (2001), Trends, rhythms and aberrations in global climate $65 \mathrm{Ma}$ to Present, Science, 292, 686-693.

Zanchi, A., F. Berra, M. Mattei, M. Ghassemi, and J. Sabouri (2006), Inversion tectonics in central Alborz, Iran, J. Struct. Geol., 28, 2023-2037.

Zanchi, A., S. Zanchetta, F. Berra, M. Mattei, E. Garzanti, S. Molyneux, A. Nawab, and J. Sabouri (2009), The Eo-Cimmerian (Late? Triassic) orogeny in north Iran, in M.-F. Brunet, M. Wilmsen and J.W. Granath (Eds.), South Caspian to Central Iran Basins, Geol Soc London Spec Publ, 312, $31-55$.

Zeitler, P. K., A. L., Herczig, I., McDougall, and M., Honda (1987), U-Th-He dating of apatite: A potential thermochronometer, Geochim Cosmochim Ac, $51,2865-2868$. 